\title{
Ability of tannins to modulate ruminal lipid metabolism and milk and meat fatty acid profiles
}

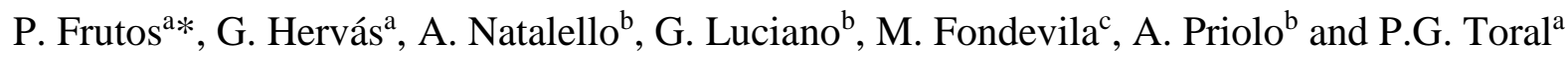

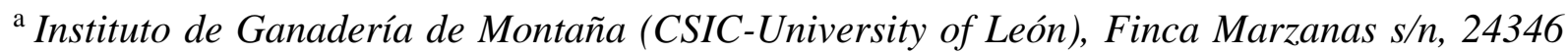
Grulleros, León, Spain

${ }^{\mathrm{b}}$ Dipartimento di Agricoltura, Alimentazione e Ambiente (Di3A), University of Catania, Via Valdisavoia 5, 95123, Catania, Italy

${ }^{\mathrm{c}}$ Departamento Producción Animal y Ciencia de los Alimentos, Instituto Agroalimentario de Aragón (IA2), Universidad de Zaragoza-CITA, Miguel Servet 177, 50013, Zaragoza, Spain

*Corresponding author. E-mail address: p.frutos@csic.es 


\section{ABSTRACT}

Tannins are a large, diverse and complex group of phenolic compounds that may be detrimental, innocuous or beneficial to animal nutrition and health depending on a number of factors (e.g., type, amount ingested, consumer animal species or the basal diet). The ability of tannins to modulate ruminal biohydrogenation and, consequently, the fatty acid (FA) composition of milk and meat is a relatively recent finding that has attracted interest among ruminant nutritionists. In this review, we take a close look at the effects of tannins on the broadest possible range of FA, including less abundant compounds that have previously received little attention. Tannins are able to improve the concentrations of potentially beneficial FA, such as $18: 3 n-3,18: 2 n-6$, trans-11 18:1 and conjugated linoleic and linolenic acids, both in milk and meat, which may contribute to meeting consumer demand for health-promoting foods. These positive responses to tannins can be explained by their modulatory action on specific biohydrogenation steps and pathways. Thus, higher contents of dietary polyunsaturated FA in ruminant-derived products, as well as increased or decreased accumulation of other biohydrogenation intermediates (e.g., cis and trans 18:3, 18:2 and 18:1 isomers) and changes in lipids of bacterial origin (odd- and branched-chain FA and dimethylacetals), are somewhat common findings when the effects of tannins are examined. In contrast, de novo synthesized FA are less frequently affected by these plant secondary metabolites, which also applies to other FA (e.g., trans-10 18:1) that might be detrimental to animal performance (i.e., milk fat synthesis) and perhaps to human health. However, further studies are required to unravel the reasons for certain erratic responses to tannins. This paper reviews the roles of tannin chemical and structural diversity, dosage, interaction with other dietary ingredients, differences among ruminant species and variations over time in the reaction of rumen microbiota in the influences of these phenolic compounds on milk and meat FA profiles. 
Key words: biohydrogenation, conjugated linoleic acid, phenolic compound, polyunsaturated fatty acid, ruminant, trans fatty acid

Abbreviations: $\mathrm{BH}$, biohydrogenation; CLA, conjugated linoleic acid; CLnA, conjugated linolenic acid; CT, condensed tannin; DM, dry matter; DMA, dimethylacetal; F:C, forage to concentrate ratio; FA, fatty acid; HT, hydrolyzable tannin; PUFA, polyunsaturated fatty acid; SCD, stearoyl-CoA desaturase. 


\section{Introduction}

At the beginning of this century, Mueller-Harvey (2006) wrote a review aiming at unravelling the conundrum of tannins in animal nutrition and health. She started this widely cited article highlighting the odd persistency of generalizations that tannins were harmful or toxic to animals. It is surprising that this erroneous perception persists nowadays, and it is long past time that we move beyond this idea.

Tannins can be detrimental, innocuous or beneficial depending on several factors, such as their type and chemical structure, the amount ingested, the consumer animal species, and the basal diet (Makkar, 2003; Patra and Saxena, 2011). All these factors together are probably responsible for the apparently inconsistent findings in the literature. First, tannins are a large and complex group of phenolic compounds with a great chemical and structural diversity. However, according to Mueller-Harvey (2006), this diversity has unfortunately been ignored or not sufficiently appreciated in many feeding trials, which has led to considerable confusion. Despite the widely used classification into hydrolyzable (HT) and condensed (CT) tannins, results obtained with a particular type of tannins cannot be extrapolated to other tannin classes (Mueller-Harvey, 2006; Patra and Saxena, 2011). In fact, tannins of different origins may differently affect nutrient availability and utilization, even when ingested at the same concentration (Schofield et al., 2001; Bueno et al., 2008). In this regard, estimations of the biological effects or reactivity of tannins would be more useful when associated with a certain type and extent of response (Makkar et al., 1995; Rodríguez et al., 2014).

Another key issue is the dietary concentration of tannins and consequently the amount that is actually consumed. The lack of standardization in the analysis of this large group of phenolic compounds and the use of different standards to express their content (e.g., tannic acid, quebracho, catechin, internal standards extracted from the plants themselves, etc.), means that direct comparisons between experiments can seldom be made (Schofield et al., 2001; Makkar, 
2003; Álvarez del Pino et al., 2005), not to mention those cases where no standards are reported.

Variations due to ruminant species, which are known to differ in their capacity to tolerate or degrade plant secondary metabolites (Pell et al. 2000; Frutos et al., 2004), and on the basal diet (Vasta et al., 2009b) are two further factors accounting for the apparent controversy in the results reported in the literature.

Thus, with all due caution, it might be said that high concentrations of tannins would reduce voluntary feed intake and nutrient digestibility (Makkar, 2003; Frutos et al., 2004), while low to moderate concentrations may exert beneficial effects on ruminant nutrition and health. These benefits would include protection of dietary protein against ruminal degradation (Frutos et al., 2004; Patra and Saxena, 2011), prevention from bloat (e.g., Wang et al., 2012; Luscher et al., 2014), anthelmintic activity (e.g., Hoste et al., 2015), reduction of methane emissions (e.g., Beauchemin et al., 2008; Bodas et al., 2012; Hristov et al., 2013), mitigation of oxidative stress (Ciampi et al., in press), or improvement of animal performance and product quality (e.g., Wang et al., 1996; Vasta and Luciano, 2011). Another relatively recent finding on the benefits of tannins is their ability to modulate ruminal biohydrogenation $(\mathrm{BH})$ and, consequently, the fatty acid (FA) compositions of milk and meat (Priolo et al., 2005; Buccioni et al., 2012; Carreño et al., 2015), which has attracted immediate interest from ruminant nutritionists and will represent the focus of this review.

The first studies reporting a positive effect of tannin consumption on milk and meat FA profile date from the early 2000s (Roy et al., 2002; Priolo et al., 2005; Turner et al., 2005). The mechanism of action was presumed to derive from changes in ruminal lipid metabolism, which was then confirmed with the use of purified tannin extracts in batch cultures of ruminal microorganisms (Kronberg et al., 2007; Vasta et al., 2009a). A number of trials on this topic, both in vitro and in vivo, have been published since then, but the results are still controversial (e.g., Jeronimo et al., 2010; Carreño et al., 2015; Buccioni et al., 2017a). 
In this review, we will first provide background information on bioactive FA in ruminantderived products and their metabolic origin. Then, we will examine the existing literature on the modulatory effects of tannins on ruminal lipid metabolism and their consequences on milk and meat FA profiles. It is worth noting that the earliest studies and reviews on this topic mostly focused on variations in major FA (e.g., $\alpha$-linolenic, rumenic, vaccenic and stearic acids; Vasta and Luciano, 2011; Morales and Ungerfeld, 2015; Toral et al., 2018), whereas changes in less abundant FA received little attention. In this article, we will try to review the effects of tannins on the broadest possible range of FA.

\section{Bioactive fatty acids in meat and milk}

Dietary guidelines aimed at reducing the risk of coronary heart disease generally recommend a low consumption of saturated fats (Salter, 2013; Parodi, 2016), so it is not surprising that ruminant fats containing high proportions of saturated FA (Shingfield et al., 2008; Scollan et al., 2017) have been perceived as detrimental to human health. Nevertheless, although 12:0, 14:0 and 16:0 can be cholesterol raising, other saturated FA may be innocuous for cardiovascular diseases (e.g., 18:0) or even healthy for consumers (e.g., 4:0 and odd- and branched-chain FA; Shingfield et al., 2008; Parodi, 2016). The demonstrated beneficial effects of dairy products on consumers' health (Elwood et al., 2008) provide an example of the importance of recognizing that saturated FA from ruminants are not consumed as a single dietary entity but along with other compounds that might counteract their possible negative effects (Lock and Bauman, 2004; Shingfield et al., 2008; Parodi, 2016). In addition, research on ruminant nutrition has demonstrated the effectiveness of some feeding strategies to improve the concentrations of bioactive FA potentially beneficial for health in milk and meat (Lock and Bauman, 2004; Scollan et al., 2017).

In this section, only a few bioactive compounds will be mentioned by way of example: 
conjugated linoleic acids (CLA), conjugated linolenic acids (CLnA), trans 18:1, n-3 polyunsaturated fatty acids (PUFA) and oxygenated FA. Milk and meat represent the major sources of CLA in the human diet, particularly the cis-9 trans-11 isomer (rumenic acid; Palmquist et al., 2005). Numerous biological properties have been attributed to this and other less prevalent CLA isomers, such as inhibition of the growth of cancer cell lines; antiatherogenic, antidiabetogenic and immunomodulatory activity; and stimulation or inhibition of lipogenesis in body tissues (Pariza et al., 2001; Shingfield et al., 2008; Pachikian et al., 2018).

Ruminants' fats may also contain CLnA isomers (e.g., cis-9 trans-11 cis-15 and cis-9 trans-13 cis-15 18:3; Hennessy et al., 2011; Saliba et al., 2014; Buccioni et al., 2015b). Nonetheless, despite the potential positive role that CLnA might play in the prevention of disease, their amount in conventional ruminant products is much lower than in certain seed oils (e.g., from pomegranate, bitter gourd and catalpa; Hennessy et al., 2011; Saliba et al., 2014).

Ruminant-derived products are major sources of trans FA. However, observations thus far suggest that the advice on limiting trans FA consumption would often be restricted to those from industrial foods, which have negative health effects, whereas the implications of ruminant trans FA intake is under debate (Kühlsen et al., 2005; Shingfield et al., 2008; Aldai et al., 2013). This is probably because trans-11 18:1 (vaccenic acid), the major trans FA in ruminant-derived products, is suggested to be health promoting (Roy et al., 2007; Tyburczy et al., 2009; Aldai et al., 2013) and is converted to cis-9 trans-11 CLA in body tissues (Palmquist et al., 2005).

Opportunities to improve the content of n-3 PUFA in meat and milk have been explored, but with inconsistent effectiveness (e.g., Chilliard et al, 2007; Dewhurst and Moloney, 2013). Evidence indicates that these PUFA are essential for neuronal development and functions and may have beneficial cardiovascular and anti-inflammatory properties (Calder, 2012; Salter, 2013). In recent years, there has been much debate about the benefits of decreasing the $n-6: n-3$ 
PUFA ratio in the diet, but conflicting results suggest that this advice might be misguided and strategies should focus on increasing total PUFA consumption, both n-3 and n-6 (Salter, 2013)

Oxygenated FA (i.e., FA with hydroxy, epoxy, methoxy and oxo substituents) have received increasing interest in recent years because of their role in the regulation of mammary inflammatory responses in dairy ruminants (Sordillo, 2018). However, we are not aware of targeted research examining the biological effects of certain oxygenated FA that are found in milk (e.g., 10-O-18:0 and 10-OH-18:0) and whose concentrations are known to be affected by diet composition, with significant increases under some milk fat-depressing conditions (Kairenius et al., 2018; Toral et al., 2018). Therefore, their actual implications for animal performance and consumer health are unknown. Although oxygenated FA are produced in the rumen during microbial FA metabolism (Alves et al., 2013) and are likely to be deposited in the intramuscular fat, fragmentary information is available on the occurrence, concentration and dietary-related changes of these compounds in meat. This paucity of information is mainly due to the fact that these FA are not reported in most studies, with only one exception (i.e., oxo18:0; Parente et al., 2020). In other instances, dietary hydroxy-FA (e.g., ricinoleic acid; 12-OH, cis-9 18:1) were detected in meat (Maia et al., 2012).

\section{Metabolic origin of fatty acids in ruminant-derived products}

From a general standpoint, FA found in ruminant milk and meat have two main origins: direct uptake of preformed FA transported in plasma and de novo synthesis in body tissues (Vernon, 1980; Palmquist, 2006). Under conventional feeding conditions, 40 to $60 \%$ of FA would derive from each source (Palmquist, 2006). In addition, both types of FA can be subjected to the action of desaturases and elongases (Jakobsson et al., 2006; Bernard et al., 2013). 


\subsection{Fatty acids of dietary and ruminal origin (preformed FA uptake)}

Preformed FA derive from the absorption of lipids in the digestive tract, so they have a dietary or ruminal origin (Moore and Christie, 1981; Jenkins et al., 2008). Body fat mobilization may also contribute but to a lower extent (Palmquist, 2006).

The major sources of dietary lipids consumed by ruminants are forages, cereal grains and oilseeds (Buccioni et al., 2012; Dewhurst and Moloney, 2013). Once in the rumen, fat is first subjected to hydrolysis by lipases, releasing free unsaturated FA (Buccioni et al., 2012). Then, rumen microorganisms biohydrogenate them to saturated FA to reduce their toxicity (Figure 1; Harfoot and Hazlewood, 1997; Jenkins et al., 2008). Nevertheless, the BH process is typically incomplete, and a vast array of intermediate metabolites leave the rumen and, after intestinal absorption, are available for incorporation into milk and meat (Palmquist, 2006). It is worth mentioning that despite the frequent low concentrations of certain $\mathrm{BH}$ intermediates (e.g., trans10 cis-12 CLA or cis-9 trans-11 cis-15 CLnA), their biological consequences on the host ruminant or the consumer may be of relevance (Shingfield et al., 2008; Hennessy et al., 2011).

Thus, modulating the $\mathrm{BH}$ process with the aim of decreasing the disappearance of dietary PUFA and optimizing the outflow of bioactive intermediates represents an appealing opportunity for ruminant nutritionists (Chilliard et al., 2007; Scollan et al., 2017). Much progress has been made in characterizing the metabolism of FA in the rumen, which is no longer assumed to be a straightforward process with few enzymatic reactions and products (Harfoot and Hazlewood, 1997). Multiple BH pathways, together with alternative hydration and oxidation reactions, have been described (Jenkins et al., 2008; Kairenius et al., 2018).

Ruminal bacteria are also able to synthesize odd- and branched-chain FA (Vlaeminck et al., 2006). Since different bacterial populations have specific FA synthetases that determine the end products of their activity, odd- and branched-chain FA in meat and milk may reflect the abundance of particular microbial groups (Vlaeminck et al., 2006, 2015). Nonetheless, some 
odd-chain FA may also have a mammary origin. Dimethylacetals (DMA) are another category of bacterial lipids that have been suggested as potential rumen microbial biomarkers and would derive from the vinyl ether chain of plasmalogens (Costa et al., 2017; Mannelli et al., 2019).

\subsection{De novo fatty acid synthesis}

Mammary and adipose tissues are the most active sites of de novo FA synthesis (Vernon, 1980; Palmquist, 2006). Rumen fermentation of carbohydrates provides the main substrates for this process: acetate and $\beta$-hydroxybutyrate for FA synthesis in mammary cells (Moore and Christie, 1981; Palmquist, 2006), and acetate and, to a lesser extent, lactate for their synthesis in adipocytes (Vernon, 1980). De novo synthesis in the mammary tissue yields the vast majority of even-chain saturated FA of 6 to 14 carbon atoms and approximately half of the 4:0 and 16:0 found in milk (Moore and Christie, 1981). Certain milk odd-chain FA may have a mammary origin through the occasional use of propionate as the precursor (Vlaeminck et al., 2006, 2015).

In non-lactating ruminants, most of the de novo FA are synthesized in adipose tissue (Vernon, 1980). This synthesis leads to the formation of FA with up to 16 carbons. Unlike the mammary tissue, where short- and medium-chain FA are incorporated rapidly into milk fat, the predominant end product of de novo synthesis in the adipose tissue is palmitic acid (16:0; Drackley et al., 2000). This FA can be used as substrate for further elongation and/or desaturation (Demeyer and Doreau 1999; Shingfield et al., 2013).

\subsection{Desaturation and elongation of fatty acids}

As noted above, preformed and de novo synthesized FA can be substrates for desaturase and elongase enzymes to produce new FA in body tissues (Jakobsson et al., 2006). The most active FA desaturase is the stearoyl-CoA desaturase (SCD), also known as $\Delta^{9}$-desaturase (Palmquist et al., 2005; Bernard et al., 2013). Although many medium- and long-chain FA serve 
as SCD substrates, only 2 will be cited here: the 18:0 (stearic acid), which is desaturated to the health-promoting cis-9 18:1 (oleic acid; Bernard et al., 2013), and the trans-11 18:1 because its conversion to cis-9 trans-11 CLA represents the main origin of this bioactive CLA in ruminantderived products (e.g., Palmquist et al., 2005; Shingfield et al., 2008; Hervás et al., 2020).

The role of elongases in milk fat synthesis, if any, seems negligible (Moore and Christie, 1981; Palmquist, 2006), while a relevant elongation activity occurs in the adipose tissue, where a significant portion of 16:0 is converted to 18:0 (Vernon, 1980; Drackley et al., 2000). Kadegowda et al. (2013) reported that the elongase processes can also involve palmitelaidic acid (trans-9 16:1), which could be first elongated to trans-11 18:1 and then desaturated to cis9 trans-11 CLA. Further activity, such as the production of n-3 and n-6 very long-chain PUFA, has been detected in adipose tissue, although it mainly occurs in liver (Cherfaoui et al., 2012).

\section{Tannins as feed additives to modulate the fatty acid composition of ruminant-derived products}

Evidence supports that the effects of tannins on the FA profile of meat and milk are explained by modulation of ruminal lipid metabolism (Kronberg et al., 2007; Khiaosa-ard et al., 2009; Vasta et al., 2009b). There is also certain consensus that the mechanism is most likely mediated by tannin-induced changes in the rumen microbial community (Mannelli et al., 2019; Vasta et al., 2019). However, the specific bacteria involved in ruminal BH of dietary PUFA are largely unknown (Jenkins et al., 2008; Enjalbert et al., 2017; Carreño et al., 2019), and consequently, so is their response to tannins (Ishlak et al., 2015; Carreño et al., 2015; Mannelli et al., 2019). For that reason, this subject will only be mentioned in passing in this article and readers are referred to a recent review by Vasta et al. (2019) for further information on the impact of plant polyphenols on rumen microbiota.

Numerous studies have examined the effects of tannins on rumen FA metabolism with 
variable success, due in part to the diversity of tannin types and concentrations that have been tested (Carreño et al., 2015; Abo-Donia et al., 2017; Alves et al., 2017). Much attention has been paid to this topic in Mediterranean and arid or semi-arid countries (e.g., Abarghuei et al., 2014; Correddu et al., 2015; Razzaghi et al., 2015), where local feed resources rich in polyphenols (e.g., bushes, spontaneous plants or agricultural byproducts) are used as nonconventional ingredients in ruminant diets. Nevertheless, based on the increasing world population, land degradation and food-fuel-feed competition, the use of alternative feed resources should be of interest at a global level (Makkar and Ankers, 2014).

The following subsections aim at providing a comprehensive review of the current knowledge on the effects of tannins on the FA composition of milk and meat. Fatty acids are grouped into 4 main categories based on their origin (i.e., dietary PUFA, ruminal intermediate metabolites, FA of bacterial origin and products of de novo synthesis). Particular attention will be paid to results of digesta FA profile because of both the consistency with milk and meat FA composition and the larger amount of information that is available, particularly in vitro (e.g., Jeronimo et al., 2010; Minieri et al., 2014; Natalello et al., 2020). In this respect, in vitro results often represent the first screening for selection of the most promising treatments to be applied in vivo. In fact, 60 out of the 72 experimental treatments that we compiled to prepare Figure 2 (please see the full list of references in Supplementary Material) showed a significant effect of CT or HT on digesta FA profile, supporting their potential application in ruminant feeding. Furthermore, as stated above, consistent changes in digesta and milk or meat FA composition have been reported in a number of studies (e.g., Loor et al., 2005; Vasta et al., 2009b; Jeronimo et al., 2010). In most cases, trials were conducted in small ruminants, especially in sheep (e.g., Correddu et al., 2015; Lobón et al., 2019; Maamouri et al., 2019), which may be related to the abovementioned geographical origin of the studies. In the absence of direct interspecies comparisons, caution should be taken before extrapolating the knowledge gained from one 
ruminant species to others.

\subsection{Effects on PUFA of dietary origin}

The more knowledge acquired on the benefits for human health of PUFA consumption (Calder, 2012; Salter, 2013), the greater the interest among ruminant nutritionists in developing strategies to protect dietary unsaturated FA from ruminal $\mathrm{BH}$ and thereby increase their concentration in meat and milk (Dewhurst and Moloney, 2013; Scollan et al., 2017). However, rumen protection technologies are not always readily available and often have a relatively low effectiveness (Lacasse et al., 2002; Dewhurst and Moloney, 2013). This fact has prompted the search for feasible alternatives, such as the use of tannins (Kronberg et al., 2007; Minieri et al., 2014; Alves et al., 2017). Reduction in the BH extent of major dietary PUFA (i.e., 18:3n-3 and 18:2n-6) in the presence of tannins, either CT or HT, is rather common in the literature. Figure 2 reports the proportion of experimental treatments causing increases, no significant changes or decreases in specific FA concentrations in digesta. Similar results for milk and meat responses are shown in Figures 3 and 4, respectively.

Increases in 18:2n-6 and 18:3n-3 concentrations in the digesta have been reported in response to very diverse tannin types (e.g., from quebracho, grape seed, chestnut, Cistus ladanifer, sainfoin, chebulic myrobalan, carob, oak or pomegranate) in trials conducted both in vitro (Vasta et al., 2009a; Rana et al., 2012; Carreño et al., 2015; Natalello et al., 2020) and in vivo (Campidonico et al., 2016; Alves et al., 2017; Buccioni et al., 2017a).

Studies on the effects of tannins on milk FA profile cover a lower diversity of tannin types than those reported above for digesta. Nevertheless, some works have confirmed the positive effects of CT from quebracho and HT from chestnut and oak on milk 18:3n-3 concentration (Buccioni et al., 2015b; Henke et al., 2017; Focant et al., 2019). This beneficial effect seems even higher (up to 2-to-3.5-fold increases) with the consumption of sainfoin hay and fresh sulla, 
rich in CT (Addis et al., 2005; Bonanno et al., 2016; Pascual et al., 2019). Increases in milk 18:2n-6 concentration with either tannin extracts or tannin-rich forages are usually less marked (Henke et al., 2017; Bonanno et al., 2016; Focant et al., 2019), which is consistent with this PUFA being rarely affected by feeding strategies (Mele et al., 2006; Glasser et al., 2008; Bernard et al., 2009). Birdsfoot trefoil pasture (rich in CT) and gallnut or mimosa tannin extracts (mostly hydrolyzable and condensed tannins, respectively) have also been proved to beneficially modify the concentration of these dietary PUFA in milk (Turner et al., 2005; AboDonia et al., 2017; de Lucena et al., 2018).

Regarding the effects of dietary tannins on meat FA composition, most studies have tested mainly CT. Notwithstanding, a rather wide selection of tannin sources has been used, including tannin extracts, as well as different tanniniferous plants and alternative feed resources. As shown in Figure 4, while in most cases the content of 18:2n-6 and 18:3n-3 in meat was not affected by feeding tannins, a number of studies reported increases in these FA. For example, quebracho tannin extracts were able to enrich lamb meat with 18:2n-6 (Kamel et al., 2018) or 18:2n-6 and 18:3n-3 (Vasta et al., 2009b). Desirable increases of these PUFA in meat were also found when animals were fed with tannin-containing forages (Priolo et al., 2005; Girard et al., 2016b) or alternative feeds (Mapiye et al., 2011; Gravador et al., 2015).

Besides 18:3n-3 and 18:2n-6, tannins can also decrease the BH extent of less-common PUFA in vegetable feeds, such as CLnA present in pomegranate seed oil (e.g., punicic acid, cis9 trans-11 cis-13 CLnA, and $\alpha$-eleostearic acid, and cis-9 trans-11 trans-13 CLnA; Natalello et al., 2020). On the contrary, lingonberry tannin extract (Vaccinium vitis-idaea; rich in CT) failed to reduce the BH extent of very long-chain n-3 PUFA from fish oil (Szczechowiak et al., 2016), although this may be explained by the low inclusion rate of the extract ( $0.45 \%$ of the diet), which is consistent with the general lack of effects on other ruminal FA.

Low levels of tannin supplementation may also account for unaffected dietary PUFA 
proportions in digesta, milk and meat lipids in several studies examining the effects of CT from sainfoin, rockrose, birdsfoot trefoil and quebracho, and HT from chestnut (Toral et al., 2011; Campidonico et al., 2016; Girard et al., 2016a; Lobón et al., 2019; Guerreiro et al., 2020). Surprisingly, Buccioni et al. (2011) observed decreases in 18:2n-6 and 18:3n-3 concentration in rumen bacteria in response to quebracho and chestnut extracts, although no similar findings have been described in total digesta content, milk or meat, except for the use of oak acorns (rich in HT; Alipanahi et al., 2019) and lotus pasture (rich in CT; Turner et al., 2015). In this regard, the inconsistent effects of tannin consumption (see Figures 2, 3 and 4) may be related not only to factors described in the Introduction, such as the type and dose of tannins or differences among ruminant species in their capacity to deal with these phenolic compounds but also to differences in experimental conditions, sample type or interactions with other dietary ingredients (see Section 5). In any event, the lack of direct comparative studies recommends caution in making speculations.

Finally, the mechanisms explaining the abovementioned effects remain uncertain. Some plant endogenous factors, such as polyphenol oxidase from red clover, decrease the overall $\mathrm{BH}$ extent of plant PUFA by protecting them from the action of lipases (Buccioni et al., 2012; Lee, 2014). Yet, this does not appear to be the mechanism of action of tannins. The ruminal response to tannins is assumed to be mediated by changes in rumen microbiota (Mannelli et al., 2019; Vasta et al., 2019), but further research is required to elucidate the main responsibility of microorganisms affected by these polyphenols (e.g., lipolysis, isomerization of free PUFA, etc.).

\subsection{Effects on intermediates of ruminal fatty acid metabolism}

This section focuses on the literature describing the ability of tannins to modify the concentration of vaccenic acid, CLA, trans-10 18:1, less-well-known BH intermediates 
(namely, certain cis and trans 18:1, 18:2, and 18:3 isomers), stearic acid, and oxo-FA.

The inhibitory action of tannins on the last step of ruminal BH (Figure 1) and, in particular, on the saturation of vaccenic acid, is probably the best characterized effect attributed to these compounds (Khiaosa-ard et al., 2009; Vasta et al., 2009a; Rana et al., 2012). The concentration of trans-11 18:1 can be increased twofold in digesta with the use of quebracho, grape and chestnut tannin extracts or Cistus ladanifer (Jeronimo et al., 2010; Vasta et al., 2010; Buccioni et al., 2017a; Costa et al., 2017). Changes in this 18:1 isomer in milk usually seem less dramatic (<100\% increase; Addis et al., 2005; Bonanno et al., 2016; de Lucena et al., 2018), which may be partly due to its conversion to cis-9 trans-11 CLA in the mammary gland (Palmquist et al., 2005; Hervás et al., 2020). In fact, extracts from quebracho (Buccioni et al., 2017b) and mimosa (de Lucena et al., 2018), as well as birdsfoot trefoil (Turner et al., 2005), sulla (Bonanno et al., 2016), Flemingia macrophylla (das Neves Oiticica et al., 2019) and oak acorns (Alipahani et al., 2019) are examples of feeds rich in either CT or HT that potentially enhance the content of cis-9 trans-11 CLA in milk. Increments in the accumulation of this desirable CLA isomer in digesta are also quite common in response to the dietary use of extracts rich in $\mathrm{CT}$ from quebracho, or HT from chestnut, oak, chebulic myrobalan or pomegranate (Rana et al., 2012; Carreño et al., 2015; Natalello et al., 2020). Nevertheless, in meat (Figure 4), the effectiveness of tannins in increasing the concentrations of trans-11 18:1 and cis-9 trans11 CLA is still controversial, with most studies reporting no effect (Brogna et al., 2014; Campidonico et al., 2016; Biondi et al., 2019; Larrain et al., 2008). In some instances, vaccenic acid was increased by rockrose or quebracho extracts (CT), with no effect on cis-9 trans-11 CLA (Vasta et al., 2009b; Guerreiro et al., 2020), while other studies reported that Terminalia chebula and carob tannins (mostly hydrolysable) increased cis-9 trans-11 CLA with no effect on vaccenic acid (Rana et al., 2012; Gravador et al., 2015). However, it should be highlighted that, differently from milk, most of the meat studies evaluated the effects of tannins using basal 
diets with a low lipid content, thus having a limited view of the possible modulatory effects of tannins on BH. Diets supplemented with lipid sources (BH substrates) could facilitate the study of BH process (Jeronimo et al., 2012; Francisco et al., 2016). Furthermore, many of these intramuscular FA profiles were not comprehensive enough to study even the most relevant FA. Indeed, it is of note that trans-11 18:1 is not reported in several studies (Lobón et al., 2017; Kamel et al., 2018; Seoni et al., 2018; Gesteira et al., 2019). Overlooked coelutions between trans-11 18:1 and other 18:1 isomers (in particular trans-10 18:1) may also exist, which obliges to be cautious in the interpretation of poorly detailed FA profiles. Finally, while most of the studies reported the FA profile of the total intramuscular lipids, only in few instances the effects of tannins were described for individual lipid fractions composing that intramuscular fat (i.e., phospholipids and triacylglycerols; Jerónimo et al., 2010; Francisco et al., 2016).

The variability in the effects of tannins on the relative proportion of trans-11 18:1 and cis-9 trans-11 CLA in digesta, milk or meat seems to be similar or even greater than that described above for dietary PUFA (see Figures 2, 3 and 4). For instance, both no effects and decreases in their ruminal or milk concentrations have been described for CT and HT (e.g., sainfoin, quebracho and chestnut) that were previously observed to induce positive changes under different experimental conditions (Buccioni et al., 2015b; Campidonico et al., 2016; Toral et al., 2016; Henke et al., 2017). In most cases, the inhibition of the initial BH of dietary PUFA, which would cause a general slowdown of the process, could account for reductions in these intermediate metabolites (Minieri et al., 2014; Campidonico et al., 2016; Henke et al., 2017).

A key reason behind the conflicting effects of tannins might be the dosage. Significant dose-dependent responses were reported by Carreño et al. (2015), who suggested that low and moderate dietary supplementation with a CT extract from grape (2 and $4 \%$ on a DM basis) decreased the first steps of 18:2n-6 BH, while higher doses (6 and 8\% DM) tended to improve trans-11 18:1 accumulation. It is worth mentioning that high levels of tannin inclusion may be 
intrinsically interesting in scientific research but will likely be impractical under farm conditions because of their cost and risk of toxicity (Makkar, 2003; Mueller-Harvey, 2006).

The role of different lipid pools in meat might also contribute to explain some inconsistent responses to tannins reported in the literature. For example, Francisco et al. (2016) reported a positive dose-dependent relationship between the level of inclusion of Cistus ladanifer (a CTrich shrub) in the diet and the concentration of total $\mathrm{C} 18 \mathrm{BH}$ intermediates in the neutral lipid fraction of muscle in lambs, whereas no effect was found in polar lipids. On the other hand, Jeronimo et al. (2010) observed that CT from grape seed and Cistus ladanifer increased total C18 BH intermediates in muscle polar but not neutral lipids.

Interspecies differences are likely another key reason explaining the controversy regarding the ability of tannins to interfere with $\mathrm{BH}$ and modulate the FA profile of milk and meat. In a work conducted with marine lipids rich in 20:5n-3 and 22:6n-3 (Toral et al., 2017), which are known to inhibit the saturation of trans-11 18:1, significant differences between cows and ewes were observed in the in vitro accumulation of this 18:1 isomer. On this basis, it may be expected that differences among ruminant species also exist in the effects of tannins on the last BH step, but this speculation must be taken with due caution.

Rumen $\mathrm{BH}$ is a very complex process with a multitude of steps and pathways, and although many authors have focused their attention on trans-11 18:1, studies in which detailed FA profiles are reported suggest that $\mathrm{CT}$ and $\mathrm{HT}$ also cause alterations in other $\mathrm{BH}$ products (Minieri et al., 2014; Campidonico et al., 2016; Alves et al., 2017). In this regard, the trans-10 pathway has attracted the interest of the scientific community due to the potential effects of certain trans-10-containing FA not only on human health but also on animal performance (Chilliard et al., 2007; Shingfield et al., 2008; Aldai et al., 2013). As shown in Figure 2, tannininduced changes in trans-10 18:1 often differ from those obtained for trans-11 18:1. Beneficial reductions in trans-10 18:1 have been described in the digesta with diets containing quebracho, 
acacia or chestnut tannins (Khiaosa-ard et al., 2009; Carreño et al., 2015; Costa et al., 2017) and in milk after fresh sulla consumption (Cabiddu et al., 2009). These findings contrast with expectations based on the effect of other modulators on the last BH step (e.g., marine lipids; Boeckaert et al., 2008; Toral et al., 2017; Kairenius et al., 2018). On the other hand, increases in milk trans-10 18:1 have also been described (Toral et al., 2013; das Neves Oiticica et al., 2019; Pascual et al., 2019), but the maximum concentration reached (approximately $2 \%$ of total FA) seems much lower than that observed in response to marine lipid supplements (up to approx. 12\% of total FA; Loor et al., 2005; Shingfield et al., 2006; Boeckaert et al., 2008). As shown in Figure 4, the available information on meat seems to suggest that both CT and HT often have no appreciable effects on the concentration of trans-10 18:1 (Biondi et al., 2019; Campidonico et al., 2016; Guerreiro et al., 2020; Larrain et al., 2008; Turner et al., 2015), although tannin-induced increases in this 18:1 isomer have been described under certain feeding conditions (e.g., when the basal diet was supplemented with plant oils; Jeronimo et al., 2010; Francisco et al., 2016). Again, as noted for the trans-11 18:1, it should be stressed that the trans$1018: 1$ isomer is not reported in several studies.

Less well-known BH pathways can also be affected by tannins. For example, variations in certain trans-13-containing FA (e.g., trans-13 18:1, cis-9 trans-13 18:2, cis-11 trans-13 CLA and trans-11 trans-13 CLA) were found when quebracho (Vasta et al., 2009a,b; Toral et al., 2013), sainfoin (Campidonico et al., 2016) or sulla (Cabiddu et al., 2009) tannins (mostly CT) were used. Nevertheless, information on these minor intermediate metabolites is too scarce to stablish generalizations on their reactions to tannins.

Characterization of the effects of tannins on the isomerization and hydrogenation steps (Figure 1) that explain variations in other 18:2 intermediate metabolites is complicated because of scarce data in the literature as well as their transient accumulation in digesta and lower concentrations in milk and meat (Toral et al., 2013; Alves et al., 2017; Alipanahi et al., 2019). 
However, effects of feeding quebracho, gallnut, sainfoin and Cistus ladanifer tannins on cis-9 trans-12, trans -9 cis-12, trans-11 cis-15, trans-10 cis-15, trans-11 trans-15 18:2 or trans-10 cis-12 and trans,trans CLA have been reported in digesta (Vasta et al., 2009b; Campidonico et al., 2016; Abo-Donia et al., 2017; Alves et al., 2017; Buccioni et al., 2017a), milk (Toral et al., 2013; Bonanno et al., 2016; Henke et al., 2017) and meat (Vasta et al., 2009b; Jerónimo et al., 2010; Francisco et al., 2015). In like manner, little information is available about changes in minor 18:3 intermediate metabolites. Yet, increases in ruminal cis-9 trans-11 cis-15 18:3 concentration have been described after the addition of a quebracho tannin extract to a diet containing linseed oil (Minieri et al., 2014).

Promotion or inhibition of the $\mathrm{BH}$ of certain cis 18:1 isomers with tannins has also been described (e.g., cis-9, -11 and -13 18:1; Khiaosa-ard et al., 2009; Buccioni et al., 2017a) and subsequently confirmed in milk (e.g., Bonanno et al., 2016; das Neves Oiticica et al., 2019; Pascual et al., 2019) and meat (Vasta et al., 2009b; Gravador et al., 2015; Gesteira et al., 2019; Guerreiro et al., 2020). In the case of the oleic acid, SCD activity would act as a confounding factor when examining the effects of tannins on meat and milk (Rana et al., 2012; Bernard et al., 2013). In digesta, the dual origin of this cis 18:1 isomer (i.e., from diet or from ruminal BH of certain PUFA) also makes it difficult to discern whether changes are due to the action of tannins on the first or last steps of BH. In any event, as shown in Figure 2, its variations in digesta seem to follow a similar pattern to that observed for trans 18:1 and dietary PUFA.

Most changes described thus far, and specifically those involving inhibition of $\mathrm{BH}$ (at the initial, intermediate or last steps), would explain the regular effects of both CT and HT by decreasing the accumulation of 18:0 (Figure 2; Vasta et al., 2009a; Rana et al., 2012; Ishlak et al., 2015). These reductions are relatively small, especially when compared with those observed with the use of other rumen BH modulators, such as marine lipids (Toral et al., 2017; Kairenius et al., 2018). In general, variations in 18:0 concentrations in milk and meat (Figures 3 and 4) 
are also limited, with minor consequences on the concentration of cis-9 18:1, the product of 18:0 desaturation in body tissues (Turner et al., 2005; Buccioni et al., 2017b).

Concerning oxo-acids, certain nutritional strategies aimed at modulating the FA profile of milk and meat, such as diet supplementation with fish oil and marine microalgae, may cause large increases in 10-oxo-18:0 (Frutos et al., 2017; Kairenius et al., 2018). In line with these results, CT from Cistus ladanifer have been found to increase 10-oxo-18:0 and decrease 16oxo-18:0 in digesta (Alves et al., 2017), whereas HT from pomegranate peels and pulp decreased not only 10- and 16- but also 13-oxo-18:0 (Natalello et al., 2020). Nevertheless, the magnitude of these changes was smaller than that obtained with marine lipid supplementation.

Finally, as described in Section 4.1 for dietary FA, in-depth information on the mechanisms explaining the effects of tannins on intermediates of ruminal FA metabolism is also missing.

\subsection{Effects on fatty acids of bacterial origin}

Figure 5 reports the effects of HT and CT on the concentration of odd- and branchedchain FA in digesta. Despite the great variability in the response reported in the literature, a high proportion of decreases in 17:0 and iso 17:0 concentrations is observed with both tannin types, and in 15:0, iso 15:0 and iso 16:0 with CT. Increases in anteiso 15:0, iso 14:0 and anteiso 17:0 are also reported, particularly with HT. According to Vlaeminck et al. (2006), a lower concentration of iso FA may suggest a reduced abundance of cellulolytic bacteria, while an increase in anteiso 15:0 would point to enhanced pectin- or sugar-fermenting bacteria. These mechanisms would explain the observed lower fiber degradability with high levels of tannins (Patra and Saxena, 2011; Vasta et al., 2019). In contrast, changes in availability of precursors (i.e., propionate and minor volatile FA) have been suggested to play a minor role in odd- and branched-chain FA content (Vlaeminck et al., 2006), even though tannins are known to modify 
the volatile FA profile in the rumen (Patra and Saxena, 2011).

As expected, consequences of tannin consumption on odd- and branched-chain FA are dose dependent. High levels of acacia, quebracho and carob tannin extracts ( $16 \%$ of the substrate) were found by Vasta et al. (2009a) to induce a consistent decrease in the in vitro ruminal concentrations of these bacterial FA. Alves et al. (2017) reported similar results, together with decreased volatile FA concentration, when examining the in vivo effects of Cistus ladanifer supplementation (50 vs. $200 \mathrm{~g} / \mathrm{kg}$ diet DM). Nevertheless, substantial variations in odd- and branched-chain FA in digesta and milk have also been described with low tannin amounts ( $\leq 3 \%$ in diet; Jeronimo et al., 2010; Buccioni et al., 2017a; Henke et al., 2017), suggesting relevant changes in specific rumen bacterial populations. In line with this, Carreño et al. (2015) reported more pronounced changes in digesta odd- and branched-chain FA with the use of HT extracts from chestnut and oak at 2 than at $8 \%$ of DM. Taken together, and once again, these findings prevent generalizations about the effects of tannins on ruminal microbiota and would support significant interactions between bacterial groups (Vasta et al., 2019).

Concerning dimethylacetals (DMA), little information is available on the effect of tannins. The results from recent in vitro trials have shown greater concentrations in total and individual DMA (e.g., DMA 13:0, 14:0, anteiso 15:0 and cis-9 18:1) in incubations with chestnut HT extracts compared with controls (i.e., no tannin addition) or CT from mimosa or grape seed (Costa et al., 2017, 2018; Mannelli et al., 2019). In any event, it is yet unclear whether these changes in DMA reflect variations in the abundance of specific microbial species or adaptations of bacterial membrane composition in response to environmental alterations (Costa et al., 2017; Mannelli et al., 2019).

\subsection{Effects on fatty acids synthesized de novo in body tissues}

The effects of tannins on de novo synthesized FA are less frequent than those described 
on FA derived from diets or ruminal metabolism and are usually of much lower extent (e.g., Aprianita et al., 2014; Buccioni et al., 2015a; Valizadeh Yonjalli et al., in press). Nevertheless, van Leeuwen et al. (2017) reported that CT from rockrose were able to mitigate the inhibition of de novo FA synthesis in meat due to dietary FA supplementation.

When the diet is supplemented with PUFA, there is a regular inhibition of mammary de novo synthesis, which is either counteracted by increased preformed FA uptake or induces milk fat depression (Bauman and Griinari, 2001; Frutos et al., 2017). However, we have found no evident relationship between the effect of tannins in increasing PUFA concentrations in digesta or milk and inhibition of mammary de novo FA synthesis (Cabiddu et al., 2009; Buccioni et al., 2015a; Pascual et al., 2019). Indeed, concomitant increases in 18:3n-3, 18:2n-6 and short- and medium-chain saturated FA concentrations in milk have been reported in assays with tannins (Addis et al., 2005; Henke et al., 2013; Lobón et al., 2019). These findings might also explain the infrequent effects of these phenolic compounds in decreasing milk fat content and yield, which could be associated with increments in total milk yield and a subsequent dilution effect (Addis et al., 2005; Bonanno et al., 2016).

Regarding the intramuscular fat, it is important to stress that tannins could have an indirect effect on de novo FA synthesis. Indeed, in cases where tannins exhibit anti-nutritional effects, with consequent reduction in ingestion and growth, the intramuscular fat deposition can be impaired (Girard et al., 2016a). Therefore, the synthesis of de novo fatty acids may also be depressed, as this lipogenic process is favored by highly energetic diets (Scollan et al., 2006). This reduction mainly concerns triglycerides (neutral lipid), as phospholipids (polar lipid) are fairly constant in the muscle (Wood et al., 2008). As a consequence, considering that phospholipids have a higher PUFA content than triglycerides (Wood et al., 2008), the PUFA proportion in the total intramuscular fat may be increased, which might lead to an incorrect interpretation of tannin effects on the modulation of $\mathrm{BH}$. 


\section{Interaction with other dietary components}

Features of basal diet composition affecting rumen microbial diversity may interfere with tannin actions on $\mathrm{BH}$. Particular focus is placed in this section on interactions with diet concentrate level, lipid-rich supplements, and other bioactive compounds.

Vasta et al. (2009b) reported that the addition of a quebracho CT extract to a forage (100\% fresh vetch) or a concentrate (30:70 alfalfa hay:concentrate) diet enhanced 18:3n-3 in the muscle of lambs, supporting an inhibition of initial BH regardless of the diet. Nonetheless, increases in trans-11 18:1 and cis-9 trans-11 CLA were only observed when tannins were included in the concentrate diet, suggesting that the forage diet prevented the perturbation of the last $\mathrm{BH}$ step. This interaction was attributed to the presence of concentrate rather than to the forage type, which agrees with results by Lobón et al. (2019) in ewes fed diets with a constant 80:20 forage to concentrate ratio: no interactions between the effects of quebracho tannin supplementation and forage type (pasture or hay) were found in the FA profiles of milk or suckling lambs' muscle.

Concerning the presence or absence of plant oils in the basal diet, CT in Cistus ladanifer only increased trans-11 18:1 and cis-9 trans-11 CLA muscle neutral lipid concentrations when the basal diet contained sunflower and linseed oils ( $6 \%$ in total), but no variation was observed without oil supplementation (Jeronimo et al. 2010). These effects on trans-11 18:1 and cis-9 trans-11 CLA were not replicated on meat and digesta in a subsequent trial showing, in addition, that the highest trans-10 18:1 concentration in muscle neutral lipids was reached when the basal diet contained plant oils (Francisco et al., 2016; Alves et al., 2017). In contrast, quebracho tannin extract was able to increase the content of 18:2n-6 in lamb meat whether or not the basal diet was supplemented with PUFA (Kamel et al., 2018). Similarly, Pascual et al. (2019) reported rather consistent effects of CT-rich sainfoin hay on milk FA profile regardless of the lipid composition of the basal diet. Given the complexity of the rumen microbiota, numerous 
interactions may occur between dietary components and tannin sources, preventing generalizations on the final effects on BH (Minieri et al., 2014; Carreño et al., 2015; Vasta et al., 2019).

Regarding other bioactive compounds, the combined use of different modulators of rumen BH might result in additive, synergistic or even antagonistic effects, depending on their different mechanisms of action. For example, Szczechowiak et al. (2016) found any interaction between tannin extracts (from oak, grape or lingonberry) and fish oil on the inhibition of the last BH step. However, the effects of sainfoin (rich in CT) and red clover (rich in polyphenol oxidase) on ruminal concentrations of $18: 3 n-3$ and certain $18: 1$ isomers were greater when used in combination (Campidonico et al., 2016). In this latter work, the fact that sainfoin and red clover did not affect rumen odd- and branched-chain FA in the same way when they were used separately would point to the involvement of different ruminal mechanisms underlying the response to each fodder legume (Buccioni et al., 2012; Lee, 2014; Vasta et al., 2019).

Pomegranate byproducts represent a particular case of feed containing different bioactive compounds, which makes it more complicated to elucidate the origin of changes. Consumption of whole pomegranate byproduct (a mixture of peels, pulp and seeds) was shown to enhance meat and milk contents of trans-11 18:1, cis-9 trans-11 CLA and CLnA in goats (Modaresi et al., 2011; Emami et al., 2015), sheep (Natalello et al., 2019; Valenti et al., 2019) and cows (Kotsampasi et al., 2017). Nonetheless, it remained unclear whether this enrichment was due to the action of the tannins present in peels and pulp (mostly hydrolyzable), the bioactive CLnA in seeds (mostly cis-9 trans-11 cis-13 CLnA), or perhaps their interaction. We showed in a recent in vitro study (Natalello et al., 2020) that pomegranate tannins and CLnA played different roles in modulating ruminal $\mathrm{BH}$ : the former would favor the accumulation of dietary PUFA (18:2n-6 or 18:3n-3) and cis-9 trans-11 CLA, whereas increases in trans-11 18:1 would mainly arise from BH of CLnA isomers. 


\section{Time-dependent effects of tannins}

Variation over time in the response of rumen microbiota to tannins may be another factor contributing to the discrepancies in the literature. Starting with in vitro assays, changes in digesta odd- and branched-chain FA concentration in the study by Natalello et al. (2020) were clearer at 24 than at $12 \mathrm{~h}$ of incubation, in agreement with consequences of gallnut extract (rich in HT) on trans-11 18:1 accumulation (Abo-Donia et al., 2017). On the other hand, reductions in certain minor 18:1 isomers were only significant in the short term (12 h; Natalello et al. 2020). In general, the results are highly inconsistent and even apparently contradictory, with the greatest effects of tannins being observed at shorter or longer in vitro incubation times depending on a multitude of variables (type, dose and reactivity of tannins, basal diet, interactions, etc.), which makes extrapolations speculative and prevents the establishment of generalizations. In any case, we consider it is worth mentioning these short-term variations because in vitro trials often constitute the first step to select treatments to be tested in vivo.

In vivo experiments including repeated measurements over time seem particularly relevant to characterize the long-term persistency of tannin-induced changes in FA metabolism, but few reports are available in this regard (e.g., Cabiddu et al., 2009; Toral et al., 2013; Buccioni et al., 2017b). Although some studies using tannin extracts have found no significant treatment $\times$ time interactions (Buccioni et al., 2015a, 2017b; Lobón et al., 2018), feeding fresh sulla (rich in CT) induced a gradual decline in trans-11 18:1 and cis-9 trans-11 CLA over time in ovine milk, with opposite changes in trans-9 trans-11 and trans-11 trans-13 CLA (Cabiddu et al., 2009). In lactating ewes, we also observed that the effects of a quebracho tannin extract on milk trans-11 18:1 and cis-9 trans-11 CLA concentrations were only transient, during the first week, and they were subsequently displaced by a gradual increase in trans-10 18:1 from day 12 onward (Toral et al., 2013). Thus, we speculated that some positive effects of tannins on 
$\mathrm{BH}$ might be compromised by time because of the potential adaptation of the ruminal microbiota. Nevertheless, changes in trans-10 18:1, which agree with slow responses reported when other rumen BH modulators were used (e.g., fish oil; Shingfield et al., 2006; Boeckaert et al., 2008), do not indicate that long-term tannin supplementation would necessarily prompt a shift in BH pathways from trans-11 to trans-10 18:1. In fact, decreased milk trans-10 18:1 concentration was found in milk from ewes fed fresh sulla for a 5-week period (Cabiddu et al., 2009). Similarly, dietary addition of $10 \%$ DM of quebracho CT for 70 days enhanced the ruminal trans-11 18:1 proportion and reduced that of trans-10 18:1 in lambs (Vasta et al., 2010), although a lower level of inclusion $(4.7 \% \mathrm{DM})$ of the same tannins increased the trans-10:trans11 FA ratio in the muscle of lambs after a similar period of supplementation (60 days; Vasta et al., 2009b). Again, differences in experimental conditions, tannin doses and basal diets, and perhaps in individual rumen microbial composition, may contribute to explain seeming contradictions in the literature.

\section{Conclusions and future perspectives}

Tannins may modulate ruminal lipid metabolism and, in consequence, modify the FA profile of milk and meat to meet consumer demand for foods perceived as health promoting. Tannins are able to improve the concentration of certain potentially beneficial FA, such as 18:3n-3, 18:2n-6, CLA, CLnA or vaccenic acid. However, unlike other feeding strategies aimed at modifying the FA profile of ruminant-derived products, tannins seem to induce smaller increases in other FA (e.g., trans-10 18:1) that might be detrimental for animal performance (i.e., milk fat synthesis) and perhaps human health. The tentative classification into HT and CT is not helpful for predicting the effect of tannins on FA metabolism.

Further studies are required to unravel the reasons for the erratic and dose-dependent responses to different tannins. Interactions between the specific tannins and the particular 
feeding conditions must be tested before implementing any strategy in practical farming. Finally, evaluation of agricultural byproducts rich in tannins represents a topic with increasing interest in this research field because their use may decrease feeding costs while improving the nutritional value of ruminant-derived products and reducing the food-fuel-feed competition at a global level.

\section{Declarations of interest: None.}

Acknowledgements: P. G. Toral benefited from a Ramón y Cajal research contract from the MINECO (RYC-2015-17230), co-funded by the European Social Fund.

\section{References}

Abarghuei, M.J., Rouzbehan, Y., Salem, A.Z.M., Zamiri, M.J. 2014. Nitrogen balance, blood metabolites and milk fatty acid composition of dairy cows fed pomegranate-peel extract. Livest. Sci. 164, 72-80.

Abo-Donia, F.M., Yang, L.Y., Hristov, A.N., Wang, M., Tang, S.X., Zhou, C.S., Han, X.F., Kang, J.H., Tan, Z.L., He, Z.X. 2017. Effects of tannins on the fatty acid profiles of rumen fluids and milk from lactating goats fed a total mixed ration containing rapeseed oil. Livest. Sci. 204, 16-24.

Addis, M., Cabiddu, A., Pinna, G., Decandia, M., Piredda, G., Pirisi, A., Molle, G. 2005. Milk and cheese fatty acid composition in sheep fed Mediterranean forages with reference to conjugated linoleic acid cis-9, trans-11. J. Dairy Sci. 88, 3443-3454.

Aldai, N., de Renobales, M., Barron, L.J.R., Kramer, J.K.G. 2013. What are the trans fatty acids issues in foods after discontinuation of industrially produced trans fats? Ruminant products, vegetable oils, and synthetic supplements. Eur. J. Lipid Sci. Technol. 115, 1378- 
1401.

Alipanahi, Z., Fatahnia, F., Jafari, H., Taasoli, G., Mirzaei-Alamouti, H., Barrett, D., Pormalekshahi, A. 2019. Effect of oak acorn with or without polyethylene glycol in diets containing extruded soybean on milk fatty acid profile, ruminal fermentation and plasma metabolites of lactating goats. Livest. Sci. 221, 57-62.

Álvarez del Pino, M.C., Hervas, G., Mantecon, A.R., Giraldez, F.J., Frutos, P. 2005. Comparison of biological and chemical methods, and internal and external standards, for assaying tannins in Spanish shrub species. J. Sci. Food Agric. 85, 583-590.

Alves, S.P., Francisco, A., Costa, M., Santos-Silva, J., Bessa, R.J.B. 2017. Biohydrogenation patterns in digestive contents and plasma of lambs fed increasing levels of a tanniferous bush (Cistus ladanifer L.) and vegetable oils. Anim. Feed Sci. Technol. 225, 157-172.

Alves, S.P., Santos-Silva, J., Cabrita, A.R., Fonseca, A.J., Bessa, R.J.B. 2013. Detailed dimethylacetal and fatty acid composition of rumen content from lambs fed lucerne or concentrate supplemented with soybean oil. PloS one 8, e58386.

Aprianita, A., Donkor, O.N., Moate, P.J., Williams, S.R.O., Auldist, M.J., Greenwood, J.S., Hannah, M.C., Wales, W.J., Vasiljevic, T. 2014. Effects of dietary cottonseed oil and tannin supplements on protein and fatty acid composition of bovine milk. J. Dairy Res. 81, 183-192.

Bauman, D.E., Griinari, J.M. 2001. Regulation and nutritional manipulation of milk fat: lowfat milk syndrome. Livest. Prod. Sci. 70, 15-29.

Beauchemin, K.A., Kreuzer, M., O'Mara, F., McAllister, T.A. 2008. Nutritional management for enteric methane abatement: a review. Aust. J. Exp. Agric. 48, 21-27.

Bernard, L., Shingfield, K.J., Rouel, J., Ferlay, A., Chilliard, Y. 2009. Effect of plant oils in the diet on performance and milk fatty acid composition in goats fed diets based on grass hay 
or maize silage. Brit. J. Nutr. 101, 213-224.

Bernard, L., Leroux, C., Chilliard, Y. 2013. Expression and nutritional regulation of stearoylCoA desaturase genes in the ruminant mammary gland: Relationship with milk fatty acid composition, in: Ntambi, J.M. (Ed.) Stearoyl-CoA desaturase genes in lipid metabolism. Springer Science+Business Media, New York, USA, pp.161-194.

Biondi, L., Randazzo, C.L., Russo, N., Pino, A., Natalello, A., Van Hoorde, K., Caggia, C. 2019. Dietary supplementation of tannin-extracts to lambs: effects on meat fatty acids composition and stability and on microbial characteristics. Foods 8, 469.

Bodas, R., Prieto, N., García-González, R., Andrés, S., Giráldez, F.J., López, S. 2012. Manipulation of rumen fermentation and methane production with plant secondary metabolites. Anim. Feed Sci. Technol. 176, 78-93.

Boeckaert, C., Vlaeminck, B., Dijkstra, J., Issa-Zacharia, A., Van Nespen, T., Van Straalen, W., Fievez, V. 2008. Effect of dietary starch or micro algae supplementation on rumen fermentation and milk fatty acid composition of dairy cows. J. Dairy Sci. 91, 4714-4727.

Bonanno, A., Di Grigoli, A., Mazza, F., De Pasquale, C., Giosuè, C., Vitale, F., Alabiso, M. 2016. Effects of ewes grazing sulla or ryegrass pasture for different daily durations on forage intake, milk production and fatty acid composition of cheese. Animal 10, 20742082.

Brogna, D.M.R., Tansawat, R., Cornforth, D., Ward, R., Bella, M., Luciano, G., Priolo, A., Villalba, J. 2014. The quality of meat from sheep treated with tannin-and saponin-based remedies as a natural strategy for parasite control. Meat Sci. 96, 744-749.

Buccioni, A., Decandia, M., Minieri, S., Molle, G., Cabiddu, A. 2012. Lipid metabolism in the rumen: New insights on lipolysis and biohydrogenation with an emphasis on the role of endogenous plant factors. Anim. Feed Sci. Technol. 174, 1-25.

Buccioni, A., Minieri, S., Rapaccini, S., Antongiovanni, M., Mele, M. 2011. Effect of chestnut 
and quebracho tannins on fatty acid profile in rumen liquid- and solid-associated bacteria: an in vitro study. Animal 5, 1521-1530.

Buccioni, A., Pallara, G., Pastorelli, R., Bellini, L., Cappucci, A., Mannelli, F., Minieri, S., Roscini, V., Rapaccini, S., Mele, M., Giovannetti, L., Viti, C., Pauselli, M. 2017a. Effect of dietary chestnut or quebracho tannin supplementation on microbial community and fatty acid profile in the rumen of dairy ewes. Biomed Res. Int. 2017, 4969076.

Buccioni, A., Pauselli, M., Minieri, S., Roscini, V., Mannelli, F., Rapaccini, S., Lupi, P., Conte, G., Serra, A., Cappucci, A., Brufani, L., Ciucci, F., Mele, M. 2017b. Chestnut or quebracho tannins in the diet of grazing ewes supplemented with soybean oil: effects on animal performances, blood parameters and fatty acid composition of plasma and milk lipids. Small Rumin. Res. 153, 23-30.

Buccioni, A., Pauselli, M., Viti, C., Minieri, S., Pallara, G., Roscini, V., Rapaccini, S., Trabalza Marinucci, M., Lupi, P., Conte, G., Mele, M. 2015a. Milk fatty acid composition, rumen microbial population, and animal performances in response to diets rich in linoleic acid supplemented with chestnut or quebracho tannins in dairy ewes. J. Dairy Sci. 98, 11451156.

Buccioni, A., Serra, A., Minieri, S., Mannelli, F., Cappucci, A., Benvenuti, D., Rapaccini, S., Conte, G., Mele, M. 2015b. Milk production, composition, and milk fatty acid profile from grazing sheep fed diets supplemented with chestnut tannin extract and extruded linseed. Small Rumin. Res. 130, 200-207.

Bueno, I.C.S., Vitti, D.M.S.S., Louvandini, H., Abdalla, A.L. 2008. A new approach for in vitro bioassay to measure tannin biological effects based on a gas production technique. Anim. Feed Sci. Technol. 141, 153-170.

Cabiddu, A., Molle, G., Decandia, M., Spada, S., Fiori, M., Piredda, G., Addis, M. 2009. Responses to condensed tannins of flowering sulla (Hedysarum coronarium L.) grazed 
by dairy sheep. Part 2: Effects on milk fatty acid profile. Livest. Sci. 123, 230-240.

Calder, P.C. 2012. Mechanisms of action of (n-3) fatty acids. J. Nutr. 142, 592S-599S.

Campidonico, L., Toral, P.G., Priolo, A., Luciano, G., Valenti, B., Hervás, G., Frutos, P., Copani, G., Ginane, C., Niderkorn, V. 2016. Fatty acid composition of ruminal digesta and longissimus muscle from lambs fed silage mixtures including red clover, sainfoin, and timothy. J. Anim. Sci. 94, 1550-1560.

Carreño, D., Hervás, G., Toral, P.G., Belenguer, A., Frutos, P. 2015. Ability of different types and doses of tannin extracts to modulate in vitro ruminal biohydrogenation in sheep. Anim. Feed Sci. Technol. 202, 45-51.

Carreño, D., Toral, P.G., Pinloche, E., Belenguer, A., Yáñez-Ruiz, D.R., Hervás, G., McEwan, N.R., Newbold, C.J., Frutos, P. 2019. Rumen bacterial community responses to DPA, EPA and DHA in cattle and sheep: A comparative in vitro study. Sci. Rep. 9, 11857.

Cherfaoui, M., Durand, D., Bonnet, M., Cassar-Malek, I., Bauchart, D., Thomas, A., Gruffat, D. 2012. Expression of enzymes and transcription factors involved in n-3 long chain PUFA biosynthesis in Limousin bull tissues. Lipids 47, 391-401.

Chilliard, Y., Glasser, F., Ferlay, A., Bernard, L., Rouel, J., Doreau, M. 2007. Diet, rumen biohydrogenation and nutritional quality of cow and goat milk fat. Eur. J. Lipid Sci. Technol. 109, 828-855.

Ciampi, F., Sordillo, L.M., Gandy, J.C., Caroprese, M., Sevi, A., Albenzio, M., Santillo, A. Evaluation of natural plant extracts as antioxidants in a bovine in vitro model of oxidative stress. J. Dairy Sci. (in press).

Correddu, F., Nudda, A., Battacone, G., Boe, R., Francesconi, A.H.D., Pulina, G. 2015. Effects of grape seed supplementation, alone or associated with linseed, on ruminal metabolism in Sarda dairy sheep. Anim. Feed Sci. Technol. 199, 61-72.

Costa, M., Alves, S., Cappucci, A., Cook, S.R., Duarte, A., Caldeira, R., McAllister, T.A., 
Bessa, R.J.B. 2018. Effects of condensed and hydrolysable tannins on rumen metabolism with emphasis on the biohydrogenation of unsaturated fatty acids. J. Sci. Food Agric. 66, $3367-3377$.

Costa, M., Alves, S.P., Cabo, Â., Guerreiro, O., Stilwell, G., Dentinho, M.T., Bessa, R.J.B. 2017. Modulation of in vitro rumen biohydrogenation by Cistus ladanifer tannins compared with other tannin sources. J. Sci. Food Agric. 97, 629-635.

das Neves Oiticica, I., da Fonseca, C.E.M., Lopes, F.C.F., Morenz, M.J.F., da Gama, M.A.S., de Souza, V.C., da Silva, A.B. 2019. Milk fatty acid composition of dairy goats fed increasing levels of Flemingia macrophylla hay. Semin. Cienc. Agrar. 40, 293-310.

de Lucena, A.R.F., Menezes, D.R., de Carvalho, D.T.Q., Matos, J.C., Antonelli, A.C., de Moraes, S.A., Dias, F.S., Queiroz, M.A.Á., Rodrigues, R.T.S. 2018. Effect of commercial tannin and a pornunça (Manihot spp.) silage-based diet on the fatty acid profile of Saanen goats' milk. Int. J. Dairy Technol. 71, 613-620.

Demeyer, D., Doreau, M. 1999. Targets and procedures for altering ruminant meat and milk lipids. Proc. Nutr. Soc. 58, 593-607.

Dewhurst, R.J., Moloney, A.P. 2013. Modification of animal diets for the enrichment of dairy and meat products with omega-3 fatty acids, in: Jacobsen, C., Nielsen, N.S., Horn, A.F. (Eds.), Food Enrichment with Omega-3 Fatty Acids. Woodhead Publishing, Cambridge, UK, pp. 257-287.

Drackley, J. K. 2000. Lipid metabolism. Chapter 5 in Farm Animal Metabolism and Nutrition: Critical Reviews. J.P.F. D'Mello (Ed.), CAB International, Wallingford, Oxon, UK, pp. 97-119.

Elwood, P.C., Givens, D.I., Beswick, A.D., Fehily, A.M., Pickering, J.E., Gallacher, J. 2008. The survival advantage of milk and dairy consumption: an overview of evidence from cohort studies of vascular diseases, diabetes and cancer. J. Am. Coll. Nutr. 27, 723S-734S. 
Emami, A., Nasri, M.H.F., Ganjkhanlou, M., Rashidi, L., Zali, A. 2015. Dietary pomegranate seed pulp increases conjugated -linoleic and -linolenic acids in muscle and adipose tissues of kid. Anim. Feed Sci. Technol. 209, 79-89.

Enjalbert, F., Combes, S., Zened, A., Meynadier, A. 2017. Rumen microbiota and dietary fat: a mutual shaping. J. Applied Microbiol. 123, 782-797.

Focant, M., Froidmont, E., Archambeau, Q., Dang Van, Q.C., Larondelle, Y. 2019. The effect of oak tannin (Quercus robur) and hops (Humulus lupulus) on dietary nitrogen efficiency, methane emission, and milk fatty acid composition of dairy cows fed a low-protein diet including linseed. J. Dairy Sci. 102, 1144-1159.

Francisco, A., Alves, S. P., Portugal, P. V., Pires, V. M. R., Dentinho, M. T., Alfaia, C. M., Jerónimo, E., Prates, J. A. M., Santos-Silva, J., Bessa, R. J. B. 2016. Effect of feeding lambs with a tanniferous shrub (rockrose) and a vegetable oil blend on fatty acid composition of meat lipids. Animal 10, 2061-2073.

Francisco, A., Dentinho, M.T., Alves, S.P., Portugal, P.V., Fernandes, F., Sengo, S., Jerónimo, E., Oliveira, M.A., Costa, P., Sequeira, A., Bessa, R.J.B. 2015. Growth performance, carcass and meat quality of lambs supplemented with increasing levels of a tanniferous bush (Cistus ladanifer L.) and vegetable oils. Meat Sci. 100, 275-282.

Frutos, P., Hervás, G., Giráldez, F.J., Mantecón, A.R. 2004. Review. Tannins and ruminant nutrition. Span. J. Agric. Res. 2, 191-202.

Frutos, P., Toral, P.G., Hervás, G. 2017. Individual variation of the extent of milk fat depression in dairy ewes fed fish oil: Milk fatty acid profile and mRNA abundance of candidate genes involved in mammary lipogenesis. J. Dairy Sci. 100, 9611-9622.

Gesteira, S.M., Oliveira, R.L., da Silva Trajano, J., Ribeiro, C.V.D.M., de Sousa Costa, E.I., Ribeiro, R.D.X., Pereira, E.S., Bezerra, L.R. 2019. Fatty acid profile, physicochemical composition and sensorial attributes of salted and sun-dried meat from young Nellore 
bulls supplemented with condensed tannins. PloS one 14, e0216047.

Girard, M., Dohme-Meier, F., Silacci, P., Ampuero Kragten, S., Kreuzer, M., Bee, G. 2016a. Forage legumes rich in condensed tannins may increase n-3 fatty acid levels and sensory quality of lamb meat. J. Sci. Food Agric. 96, 1923-1933.

Girard, M., Dohme-Meier, F., Wechsler, D., Goy, D., Kreuzer, M., Bee, G. 2016b. Ability of 3 tanniferous forage legumes to modify quality of milk and Gruyère-type cheese. J. Dairy Sci. 99, 205-220.

Gravador, R.S., Luciano, G., Jongberg, S., Bognanno, M., Scerra, M., Andersen, M.L., Lund, M.N., Priolo, A. 2015. Fatty acids and oxidative stability of meat from lambs fed carobcontaining diets. Food Chem. 182, 27-34.

Guerreiro, O., Alves, S.P., Soldado, D., Cachucho, L., Almeida, J.M., Francisco, A., SantosSilva, J., Bessa, R.J., Jerónimo, E. 2020. Inclusion of the aerial part and condensed tannin extract from Cistus ladanifer L. in lamb diets-Effects on growth performance, carcass and meat quality and fatty acid composition of intramuscular and subcutaneous fat. Meat Sci. 160, 107945.

Glasser, F., Ferlay, A., Chilliard, Y. 2008. Oilseed lipid supplements and fatty acid composition of cow milk: A meta-analysis. J. Dairy Sci. 91, 4687-4703.

Harfoot, C.G., Hazlewood, G.P. 1997. Lipid metabolism in the rumen, in: Hobson, P.N., Stewart, C.S. (Eds.) The Rumen Microbial Ecosystem. Chapman and Hall, London, UK, pp. 382-426.

Henke, A., Westreicher-Kristen, E., Molkentin, J., Dickhoefer, U., Knappstein, K., Hasler, M., Susenbeth, A. 2017. Effect of dietary quebracho tannin extract on milk fatty acid composition in cows. J. Dairy Sci. 100, 6229-6238.

Hennessy, A.A., Ross, R.P., Devery, R., Stanton, C. 2011. The health promoting properties of the conjugated isomers of $\alpha$-linolenic acid. Lipids 46, 105-119. 
Hervás, G.; Frutos, P. and Toral, P.G. 2020. Endogenous synthesis of milk cis-9 trans-11 CLA in dairy ewes: quantification using ${ }^{13} \mathrm{C}$-labeled vaccenic acid and comparison with estimations based on cobalt administration. J. Dairy Sci. 103, 368-378.

Hoste, H., Torres-Acosta, J.F.J., Sandoval-Castro, C.A., Mueller-Harvey, I., Sotiraki, S., Louvandini, H., Thamsborg, S.M., Terrill, T.H. 2015. Tannin containing legumes as a model for nutraceuticals against digestive parasites in livestock. Vet. Parasitol. 212, 5-17.

Hristov, A.N., Oh, J., Firkins, J.L., Dijkstra, J., Kebreab, E., Waghorn, G., Makkar, H.P.S., Adesogan, A.T., Yang, W., Lee, C., Gerber, P.J., Henderson, B., Tricarico, J.M. 2013. Mitigation of methane and nitrous oxide emissions from animal operations: I. A review of enteric methane mitigation options. J. Anim. Sci. 91, 5045-5069.

Ishlak, A., Günal, M., AbuGhazaleh, A.A. 2015. The effects of cinnamaldehyde, monensin and quebracho condensed tannin on rumen fermentation, biohydrogenation and bacteria in continuous culture system. Anim. Feed Sci. Technol. 207, 31-40.

Jakobsson, A., Westerberg, R., Jacobsson, A. 2006. Fatty acid elongases in mammals: Their regulation and roles in metabolism. Progr. Lipid Res. 45, 237-249.

Jenkins, T.C., Wallace, R.J., Moate, P.J., Mosley, E.E. 2008. Board-invited review: Recent advances in biohydrogenation of unsaturated fatty acids within the rumen microbial ecosystem. J. Anim. Sci. 86, 397-412.

Jeronimo, E., Alves, S.P., Dentinho, M.T.P., Martins, S.V., Prates, J.A.M., Vasta, V., SantosSilva, J., Bessa, R.J.B. 2010. Effect of grape seed extract, Cistus ladanifer L., and vegetable oil supplementation on fatty acid composition of abomasal digesta and intramuscular fat of lambs. J. Sci. Food Agric. 58, 10710-10721.

Jerónimo, E., Alfaia, C.M., Alves, S.P., Dentinho, M.T., Prates, J.A., Vasta, V., Santos-Silva, J., Bessa, R.J. 2012. Effect of dietary grape seed extract and Cistus ladanifer L. in combination with vegetable oil supplementation on lamb meat quality. Meat Sci. 92, 841- 
847.

Kadegowda, A.K.G., Burns, T.A., Miller, M.C., Duckett, S.K. 2013. Cis-9, trans-11 conjugated linoleic acid is endogenously synthesized from palmitelaidic (C16:1 trans-9) acid in bovine adipocytes. J. Anim. Sci. 91, 1614-1623.

Kairenius, P., Leskinen, H., Toivonen, V., Muetzel, S., Ahvenjärvi, S., Vanhatalo, A., Huhtanen, P., Wallace, R.J., Shingfield, K.J. 2018. Effect of dietary fish oil supplements alone or in combination with sunflower and linseed oil on ruminal lipid metabolism and bacterial populations in lactating cows. J. Dairy Sci. 101, 3021-3035.

Kamel, H.E.M., Al-Dobaib, S.N., Salem, A.Z., López, S., Alaba, P.A. 2018. Influence of dietary supplementation with sunflower oil and quebracho tannins on growth performance and meat fatty acid profile of Awassi lambs. Anim. Feed Sci. Technol. 235, 97-104.

Khiaosa-ard, R., Bryner, S.F., Scheeder, M.R.L., Wettstein, H.R., Leiber, F., Kreuzer, M., Soliva, C.R. 2009. Evidence for the inhibition of the terminal step of ruminal alphalinolenic acid biohydrogenation by condensed tannins. J. Dairy Sci. 92, 177-188.

Kotsampasi, B., Christodoulou, C., Tsiplakou, E., Mavrommatis, A., Mitsiopoulou, C., Karaiskou, C., Dotas, V., Robinson, P.H., Bampidis, V.A., Christodoulou, V., Zervas, G. 2017. Effects of dietary pomegranate pulp silage supplementation on milk yield and composition, milk fatty acid profile and blood plasma antioxidant status of lactating dairy cows. Anim. Feed Sci. Technol. 234, 228-236.

Kronberg, S.L., Scholljegerdes, E.J., Barcelo-Coblijn, G., Murphy, E.J. 2007. Flaxseed treatments to reduce biohydrogenation of alpha-linolenic acid by rumen microbes in cattle. Lipids 42, 1105-1111.

Kühlsen, N., Pfeuffer, M., Soustre, Y., MacGibbon, A., Lindmark-Mansson, H., Schrezenmeir, J. 2005. Trans fatty acids: Scientific progress and labelling. Bull. Int. Dairy Fed. 393, 119. 
Lacasse, P., Kennelly, J.J., Delbecchi, L., Ahnadi, C.E. 2002. Addition of protected and unprotected fish oil to diets for dairy cows. I. Effects on the yield, composition and taste of milk. J. Dairy Res. 69, 511-520.

Larraín, R.E., Schaefer, D.M., Richards, M.P., Reed, J.D. 2008. Finishing steers with diets based on corn, high-tannin sorghum or a mix of both: Color and lipid oxidation in beef. Meat Sci. 79, 656-665.

Lee, M.R.F. 2014. Forage polyphenol oxidase and ruminant livestock nutrition. Front. Plant Sci. 5:694.

Lobón, S., Blanco, M., Sanz, A., Ripoll, G., Bertolín, J.R., Joy, M. 2017. Meat quality of light lambs is more affected by the dam's feeding system during lactation than by the inclusion of quebracho in the fattening concentrate. J. Anim. Sci. 95, 4998-5011.

Lock, A.L., Bauman, D.E. 2004. Modifying milk fat composition of dairy cows to enhance fatty acids beneficial to human health. Lipids 39, 1197-1206.

Loor, J.J., Ferlay, A., Ollier, A., Ueda, K., Doreau, M., Chilliard, Y. 2005. High-concentrate diets and polyunsaturated oils alter trans and conjugated isomers in bovine rumen, blood, and milk. J. Dairy Sci. 88, 3986-3999.

Luscher, A., Mueller-Harvey, I., Soussana, J.F., Rees, R.M., Peyraud, J.L. 2014. Potential of legume-based grassland-livestock systems in Europe: a review. Grass Forage Sci. 69, 206-228.

Maamouri, O., Mahouachi, M., Kraiem, K., Atti, N. 2019. Milk production, composition and milk fatty acid profile from grazing ewes fed diets supplemented with Acacia cyanophylla leaves as tannins source and whole or extruded linseed. Livest. Sci. 227, 120-127.

Maia, M.D.O., Susin, I., Pires, A.V., Gentil, R.S., Ferreira, E.M., Mendes, C.Q., Alencar, S.M.D. 2012. Growth, carcass characteristics, chemical composition and fatty acid profile of the longissimus dorsi muscle in goat kids fed diets with castor oil. R. Bras. Zootec. 41, 
2343-2349.

Makkar, H.P.S., Ankers P. 2014. Towards sustainable animal diets: A survey-based study. Anim. Feed Sci. Technol. 198, 309-322.

Makkar, H.P.S. 2003. Effects and fate of tannins in ruminant animals, adaptation to tannins, and strategies to overcome detrimental effects of feeding tannin-rich feeds. Small Rum. Res. 49, 241-256.

Makkar, H.P.S., Blummel, M., Becker, K., 1995. Formation of complexes between polyvinyl pyrrolidone or polyethylene glycol and tannins, and their implications in gas production and true digestibility in in vitro techniques. Br. J. Nutr. 73, 897-913.

Mannelli, F., Daghio, M., Alves, S.P., Bessa, R.J.B., Minieri, S., Giovannetti, L., Conte, G., Mele, M., Messini, A., Rapaccini, S., Viti, C., Buccioni, A. 2019. Effects of chestnut tannin extract, vescalagin and gallic acid on the dimethyl acetals profile and microbial community composition in rumen liquor: an in vitro study. Microorganisms 7, 202.

Mapiye, C., Chimonyo, M., Dzama, K., Hugo, A., Strydom, P.E., Muchenje, V., 2011. Fatty acid composition of beef from Nguni steers supplemented with Acacia karroo leaf-meal. J. Food Compos. Anal. 24,.523-528.

Mele, M., Buccioni, A., Petacchi, F., Serra, A., Banni, S., Antongiovanni, M., Secchiari, P. 2006. Effect of forage/concentrate ratio and soybean oil supplementation on milk yield, and composition from Sarda ewes. Anim. Res. 55, 273-285.

Minieri, S., Buccioni, A., Rapaccini, S., Pezzati, A., Benvenuti, D., Serra, A., Mele, M. 2014. Effect of quebracho tannin extract on soybean and linseed oil biohydrogenation by solid associated bacteria: an in vitro study. Ital. J. Anim. Sci. 13, 604-608.

Modaresi, J., Nasri, M.H.F., Rashidi, L., Dayani, O., Kebreab, E. 2011. Short communication: Effects of supplementation with pomegranate seed pulp on concentrations of conjugated linoleic acid and punicic acid in goat milk. J. Dairy Sci. 94, 4075-4080. 
Moore, J.H., Christie, W.W. 1981. Lipid metabolism in the mammary gland of ruminant animals, in: Christie, W.W. (Ed.) Lipid metabolism in ruminant animals. Pergamon Press Ltd., Oxford, UK, pp. 227-278.

Morales, R., Ungerfeld, E.M. 2015. Use of tannins to improve fatty acids profile of meat and milk quality in ruminants: A review. Chil. J. Agric. Res. 75, 239-248.

Mueller-Harvey, I. 2006. Review. Unravelling the conundrum of tannins in animal nutrition and health. J. Sci. Food Agric. 86, 2010-2037.

Natalello, A., Luciano, G., Morbidini, L., Valenti, B., Pauselli, M., Frutos, P., Biondi, L., Rufino-Moya, P.J., Lanza, M., Priolo, A. 2019. Effect of feeding pomegranate byproduct on fatty acid composition of ruminal digesta, liver, and muscle in lambs. J. Agric. Food Chemi. 67, 4472-4482.

Natalello, A., Hervás, G., Toral, P.G., Luciano, G., Valenti, B., Mendoza, A.G., Pauselli, M., Priolo, A., Frutos, P. 2020. Bioactive compounds from pomegranate by-products increase the in vitro ruminal accumulation of potentially health promoting fatty acids. Anim. Feed Sci. Technol. 259, 114355.

Pachikian, B.D., Druart, C., Catry, E., Bindels, L.B., Neyrinck, A.M., Larondelle, Y., Cani, P.D., Delzenne, N.M. 2018. Implication of trans-11,trans-13 conjugated linoleic acid in the development of hepatic steatosis. PLoS One 13, e0192447.

Palmquist, D.L., Lock, A.L., Shingfield, K.J., Bauman, D.E. 2005. Biosynthesis of conjugated linoleic acid in ruminants and humans, in: Taylor, S.L. (Ed.) Advances in Food and Nutrition Research. Elsevier Academic Press, San Diego, USA, pp. 179-217.

Palmquist, D.L. 2006. Milk Fat: Origin of Fatty Acids and Influence of Nutritional Factors Thereon, in: Fox, P.F., McSweeney, P.L.H. (Eds.) Advanced Dairy Chemistry, Volume 2: Lipids, 3rd edition. Springer, New York, USA, pp. 43-92.

Parente, M.D.O.M., Rocha, K.S., Bessa, R.J.B., Parente, H.N., de Moura Zanine, A., Machado, 
N.A.F., Júnior, J.D.B.L., Bezerra, L.R., Landim, A.V., Alves, S.P. 2020. Effects of the dietary inclusion of babassu oil or buriti oil on lamb performance, meat quality and fatty acid composition. Meat Sci. 160, 107971.

Pariza, M.W., Park, Y., Cook, M.E. 2001. The biologically active isomers of conjugated linoleic acid. Progr. Lipid Res. 40, 283-298.

Parodi, P.W. 2016. Dietary guidelines for saturated fatty acids are not supported by the evidence. Int. Dairy J. 52, 115-123.

Pascual, A., Pineda-Quiroga, C., Goiri, I., Atxaerandio, R., Ruiz, R., García-Rodríguez, A. 2019. Effects of feeding UFA-rich cold-pressed oilseed cakes and sainfoin on dairy ewes' milk fatty acid profile and curd sensory properties. Small Rumin. Res. 175, 96-103.

Patra, A.K., Saxena, J. 2011. Exploitation of dietary tannins to improve rumen metabolism and ruminant nutrition. J. Sci. Food Agric. 91, 24-37.

Pell, A.N., Woolston, T.K., Nelson, K.E., Schofield, P. 2000. Tannins: Biological activity and bacterial tolerance, in: Brooker, J.D. (Ed.), Tannins in livestock and human nutrition. ACIAR Proceedings No. 92, Adelaide, Australia, pp. 111-117.

Priolo, A., Bella, M., Lanza, M., Galofaro, V., Biondi, L., Barbagallo, D., Salem, H.B., Pennisi, P. 2005. Carcass and meat quality of lambs fed fresh sulla (Hedysarum coronarium L.) with or without polyethylene glycol or concentrate. Small Rumin. Res. 59, 281-288.

Rana, M.S., Tyagi, A., Hossain, S.A., Tyagi, A.K. 2012. Effect of tanniniferous Terminalia chebula extract on rumen biohydrogenation, $\Delta^{9}$-desaturase activity, CLA content and fatty acid composition in longissimus dorsi muscle of kids. Meat Sci. 90, 558-563.

Razzaghi, A., Naserian, A.A., Valizadeh, R., Ebrahimi, S.H., Khorrami, B., Malekkhahi, M., Khiaosa-ard, R. 2015. Pomegranate seed pulp, pistachio hulls, and tomato pomace as replacement of wheat bran increased milk conjugated linoleic acid concentrations without adverse effects on ruminal fermentation and performance of Saanen dairy goats. Anim. 
Feed Sci. Technol. 210, 46-55.

Rodríguez, R., de la Fuente, G., Gómez, S., Fondevila, M. 2014. Biological effect of tannins from different vegetal origin on microbial and fermentation traits in vitro. Anim. Prod. Sci. 54, 1039-1046.

Roy, A., Chardigny, J.M., Bauchart, D., Ferlay, A., Lorenz, S., Durand, D., Gruffat, D., Faulconnier, Y., Sébédio, J.L., Chilliard, Y. 2007. Butters rich either in trans-10-C18:1 or in trans-11-C18:1 plus cis-9, trans-11 CLA differentially affect plasma lipids and aortic fatty streak in experimental atherosclerosis in rabbits. Animal 1, 467-476.

Roy, N.C., Knight, T.W., Reynolds, G.W., Deighton, M.H., Death, A.F., Sinclair, B.R., Peters, J.S., McNabb, W.C. 2002. The effect of condensed-tannins in fresh sulla (Hedysarum coronarium) on the net flux of fatty acids across the mammary gland and their secretion in the milk of lactating ewes. Proc. New Zeal. Soc. Anim. Prod. 62, 231-235.

Saliba, L., Gervais, R., Lebeuf, Y., Chouinard, P.Y. 2014. Effect of feeding linseed oil in diets differing in forage to concentrate ratio: 1 . Production performance and milk fat content of biohydrogenation intermediates of a- linolenic acid. J. Dairy Res. 81, 82-90.

Salter, A.M. 2013. Dietary fatty acids and cardiovascular disease. Animal 7, 163-171.

Schofield, P., Mbugua, D.M., Pell, A.N. 2001. Analysis of condensed tannins: a review. Anim. Feed Sci. Technol. 91, 21-40.

Scollan, N.D., Price, E.M., Morgan, S.A., Huws, S.A., Shingfield, K.J. 2017. Can we improve the nutritional quality of meat? Proc. Nutr. Soc. 76, 603-618.

Scollan, N., Hocquette, J.F., Nuernberg, K., Dannenberger, D., Richardson, I., Moloney, A. 2006. Innovations in beef production systems that enhance the nutritional and health value of beef lipids and their relationship with meat quality. Meat Sci. 74, 17-33.

Seoni, E., Battacone, G., Silacci, P., Ampuero Kragten, S., Messadene Chelali, J., DohmeMeier, F., Bee, G. 2018. Effect of condensed tannins from Birdsfoot trefoil and dietary 
protein level on growth performance, carcass composition and meat quality of ram lambs. Small Rumin. Res. 169, 118-126.

Shingfield, K.J., Bonnet, M., Scollan, N.D. 2013. Recent developments in altering the fatty acid composition of ruminant-derived foods. Animal 7, 132-162.

Shingfield, K.J., Reynolds, C.K., Hervás, G., Griinari, J.M., Grandison, A.S., Beever, D.E. 2006. Examination of the persistency of milk fatty acid composition responses to fish oil and sunflower oil in the diet of dairy cows. J. Dairy Sci. 89, 714-732.

Shingfield, K.J., Chilliard, Y., Toivonen, V., Kairenius, P., Givens, D.I. 2008. Trans fatty acids and bioactive lipids in ruminant milk. Adv. Exp. Med. Biol. 606, 3-65.

Sordillo, L.M. 2018. Symposium review: Oxylipids and the regulation of bovine mammary inflammatory responses. J. Dairy Sci., 5629-5641.

Szczechowiak, J., Szumacher-Strabel, M., El-Sherbiny, M., Pers-Kamczyc, E., Pawlak, P., Cieslak, A. 2016. Rumen fermentation, methane concentration and fatty acid proportion in the rumen and milk of dairy cows fed condensed tannin and/or fish-soybean oils blend. Anim. Feed Sci. Technol. 216, 93-107.

Toral, P.G., Hervás, G., Carreño, D., Leskinen, H., Belenguer, A., Shingfield, K.J., Frutos, P. 2017. In vitro response to EPA, DPA, and DHA: Comparison of effects on ruminal fermentation and biohydrogenation of 18-carbon fatty acids in cows and ewes. J. Dairy Sci. 100, 6187-6198.

Toral, P.G., Hervás, G., Belenguer, A., Bichi, E., Frutos, P. 2013. Effect of the inclusion of quebracho tannins in a diet rich in linoleic acid on milk fatty acid composition in dairy ewes. J. Dairy Sci. 96, 431-439.

Toral, P.G., Hervás, G., Bichi, E., Belenguer, A., Frutos, P. 2011. Tannins as feed additives to modulate ruminal biohydrogenation: Effects on animal performance, milk fatty acid composition and ruminal fermentation in dairy ewes fed a diet containing sunflower oil. 
Anim. Feed Sci. Technol. 164, 199-206.

Toral, P.G., Hervás, G., Missaoui, H., Andrés, S., Giráldez, F.J., Jellali, S., Frutos, P. 2016. Effects of a tannin-rich legume (Onobrychis viciifolia) on in vitro ruminal biohydrogenation and fermentation. Span. J. Agric. Res. 14, e0602.

Toral, P.G., Monahan, F.J., Hervás, G., Frutos, P., Moloney, A.P. 2018. Review: Modulating ruminal lipid metabolism to improve the fatty acid composition of meat and milk. Challenges and opportunities. Animal 12, s272-s281.

Turner, K.E., Cassida, K.A., Zerby, H.N., Brown, M.A., 2015. Carcass parameters and meat quality in meat-goat kids finished on chicory, birdsfoot trefoil, or red clover pastures. Meat Sci. 105, 68-74.

Turner, S.-A., Waghorn, G.C., Woodhard, S.L., Thomson, N.A. 2005. Condensed tannins in birdsfoot trefoil (Lotus corniculatus) affect the detailed composition of milk from dairy cows. Proc. New Zeal. Soc. Anim. Prod. 65, 283-289.

Tyburczy, C., Major, C., Lock, A.L., Destaillats, F., Lawrence, P., Brenna, J.T., Salter, A.M., Bauman, D.E. 2009. Individual trans octadecenoic acids and partially hydrogenated vegetable oil differentially affect hepatic lipid and lipoprotein metabolism in golden syrian hamsters. J. Nutr. 139, 257-263.

Valenti, B., Luciano, G., Morbidini, L., Rossetti, U., Codini, M., Avondo, M., Priolo, A., Bella, M., Natalello, A., Pauselli, M. 2019. Dietary pomegranate pulp: effect on ewe milk quality during late lactation. Animals 9, 283.

Valizadeh Yonjalli, R., Mirzaei Aghjehgheshlagh, F., Mahdavi, A., Navidshad, B., Staji, H. The effects of tannin extract and linseed oil on yield, physicochemical characteristics and fatty acid profile of ewe milk. Int. J. Dairy Technol. (in press).

Van Leeuwen, K.A., Camin, F., Jerónimo, E., Vasta, V., Prenzler, P.D., Ryan, D., Bessa, R.J. 2017. Dietary effects on stable carbon isotope composition of fatty acids in polar and 
neutral fractions of intramuscular fat of lambs. J. Agric. Food Chem. 65, 9404-9411.

Vasta, V., Daghio, M., Cappucci, A., Buccioni, A., Serra, A., Viti, C., Mele, M. 2019. Invited review: Plant polyphenols and rumen microbiota responsible for fatty acid biohydrogenation, fiber digestion, and methane emission: Experimental evidence and methodological approaches. J. Dairy Sci. 102, 3781-3804.

Vasta, V., Luciano, G. 2011. The effects of dietary consumption of plants secondary compounds on small ruminants' products quality. Small Rum. Res. 101, 150-159.

Vasta, V., Makkar, H.P.S., Mele, M., Priolo, A. 2009a. Ruminal biohydrogenation as affected by tannins in vitro. Br. J. Nutr. 102, 82-92.

Vasta, V., Mele, M., Serra, A., Scerra, M., Luciano, G., Lanza, M., Priolo, A. 2009b. Metabolic fate of fatty acids involved in ruminal biohydrogenation in sheep fed concentrate or herbage with or without tannins. J. Anim. Sci. 87, 2674-2684.

Vasta, V., Yañez-Ruiz, D.R., Mele, M., Serra, A., Luciano, G., Lanza, M., Biondi, L., Priolo, A. 2010. Bacterial and protozoal communities and fatty acid profile in the rumen of sheep fed a diet containing added tannins. Appl. Environ. Microbiol. 76, 2549-2555.

Vernon, R.G. 1980. Lipid metabolism in the adipose tissue of ruminant animals. Progr. Lipid Res. 19, 23-106.

Vlaeminck, B., Fievez, V., Cabrita, A.R.J., Fonseca, A.J.M., Dewhurst, R.J. 2006. Factors affecting odd- and branched-chain fatty acids in milk: A review. Anim. Feed Sci. Technol. $131,389-417$.

Vlaeminck, B., Gervais, R., Rahman, M.M., Gadeyne, F., Gorniak, M., Doreau, M., Fievez, V. 2015. Postruminal synthesis modifies the odd- and branched-chain fatty acid profile from the duodenum to milk. J. Dairy Sci. 98, 4829-4840.

Wang, Y., Douglas, G.B., Waghorn, G.C., Barry, T.N., Foote, A.G. 1996. Effect of condensed tannins in Lotus corniculatus upon lactation performance in dairy ewes. J. Agric. Sci. 127, 
353-362.

Wang, Y., Majak, W., McAllister, T.A. 2012. Frothy bloat in ruminants: Cause, occurrence, and mitigation strategies. Anim. Feed Sci. Technol. 172, 103-114.

Wood, J.D., Enser, M., Fisher, A.V., Nute, G.R., Sheard, P.R., Richardson, R.I., Hughes, S.I., Whittington, F.M. 2008. Fat deposition, fatty acid composition and meat quality: A review. Meat Sci. 78, 343-358. 


\section{Figure 1}

Pathways of dietary unsaturated fatty acid (FA) metabolism in the rumen.

\section{Figure 2}

Proportion of experimental treatments containing hydrolyzable or condensed tannins (HT and $\mathrm{CT}$, respectively) that cause increases, no significant changes or decreases in the concentrations of selected fatty acids in digesta. Data are derived from 23 individual studies, reported in Supplementary Material, corresponding to 72 dietary treatments.

\section{Figure 3}

Proportion of experimental treatments containing hydrolyzable or condensed tannins (HT and $\mathrm{CT}$, respectively) that cause increases, no significant changes or decreases in the concentrations of selected fatty acids in milk. Data are derived from 26 individual studies, reported in Supplementary Material, corresponding to 46 dietary treatments.

\section{Figure 4}

Proportion of experimental treatments containing hydrolyzable or condensed tannins (HT and $\mathrm{CT}$, respectively) that cause increases, no significant changes or decreases in the concentrations of selected fatty acids in meat. Data are derived from 22 individual studies, reported in Supplementary Material, corresponding to 40 dietary treatments.

\section{Figure 5}

Proportion of experimental treatments containing hydrolyzable or condensed tannins (HT and $\mathrm{CT}$, respectively) that cause increases, no significant changes or decreases in the concentrations of odd- and branched-chain fatty acids in digesta. Data are derived from 13 individual studies, reported in Supplementary Material, corresponding to 52 dietary treatments. 
FIGURE 1

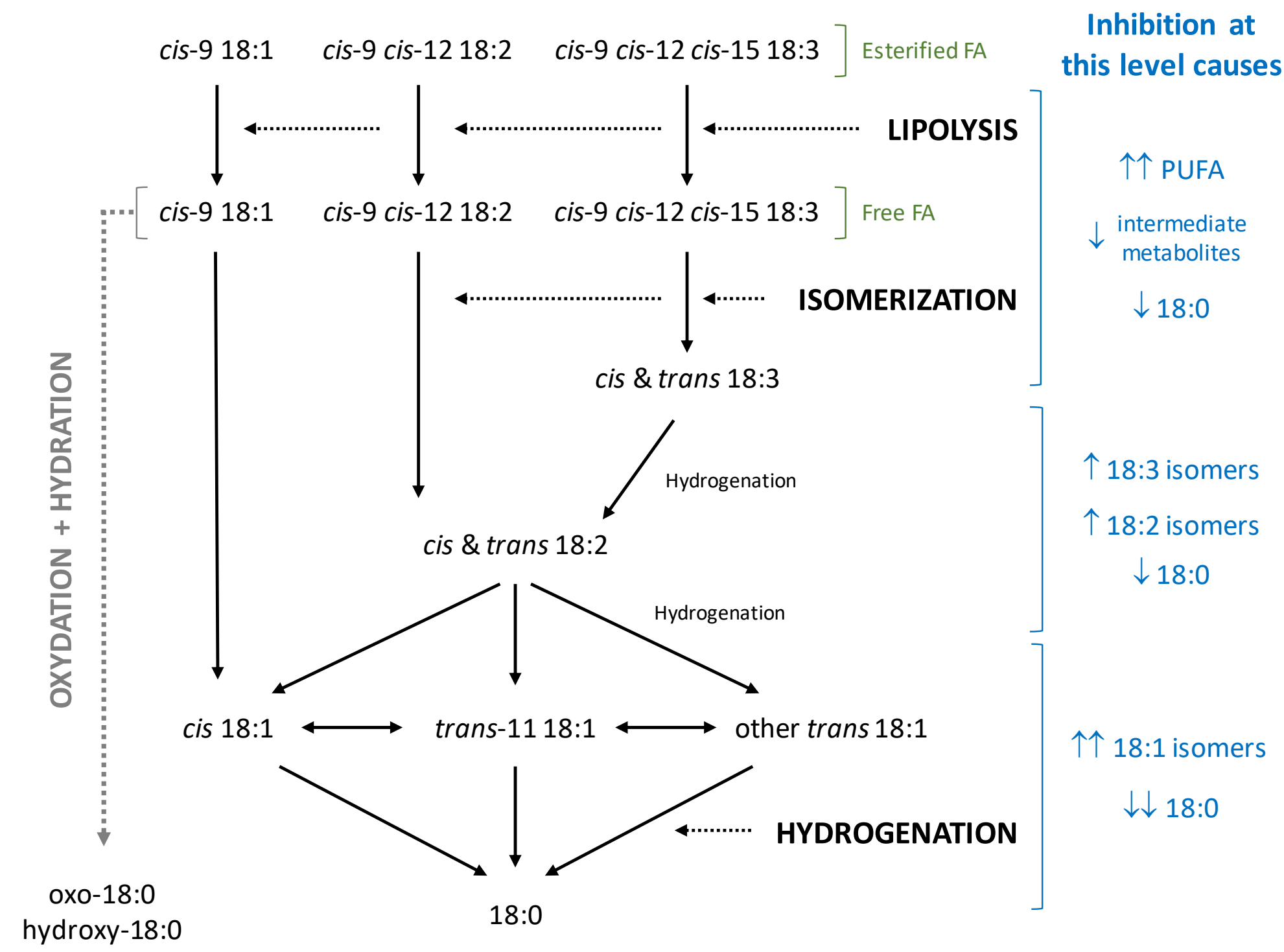


FIGURE 2

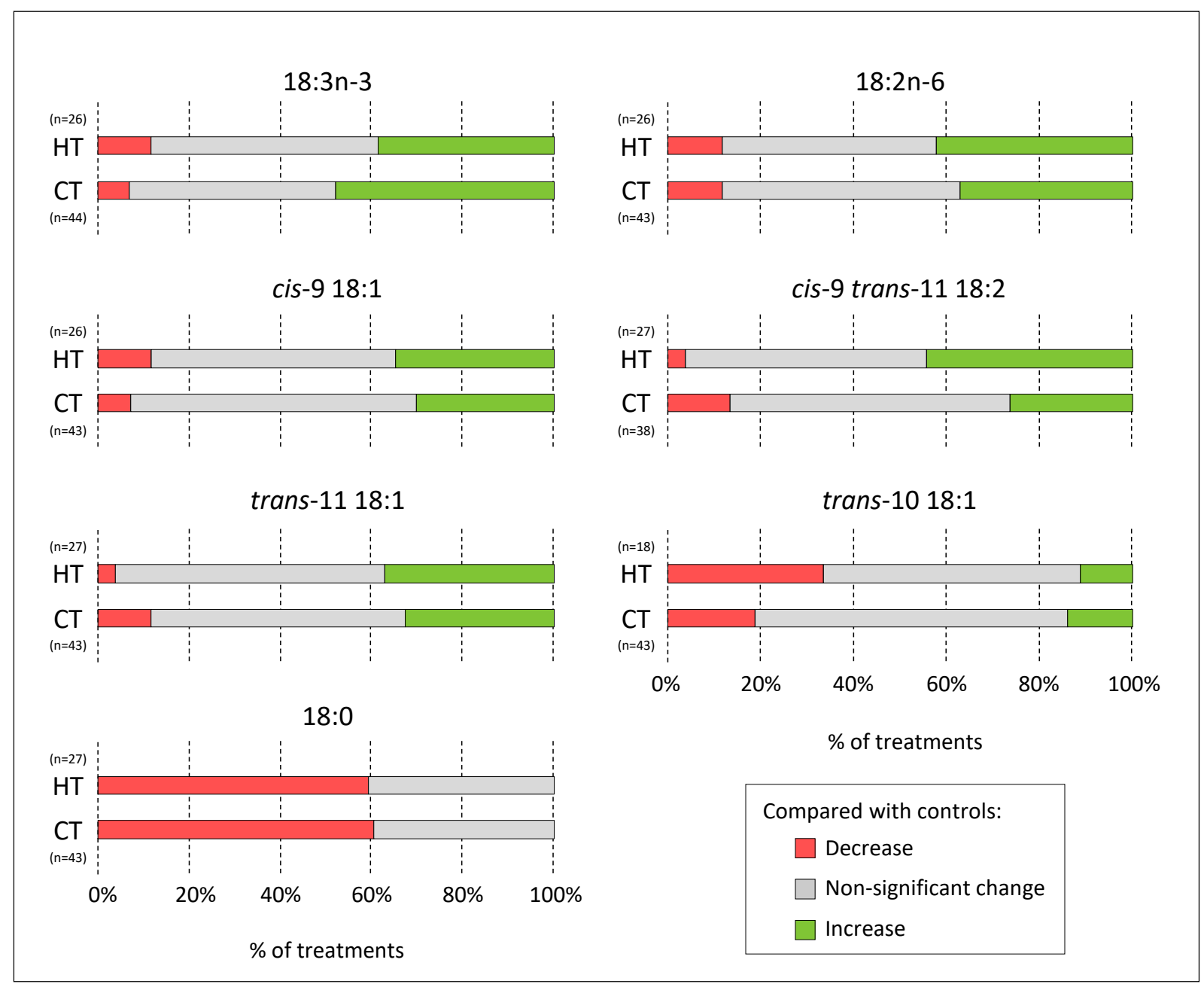


FIGURE 3

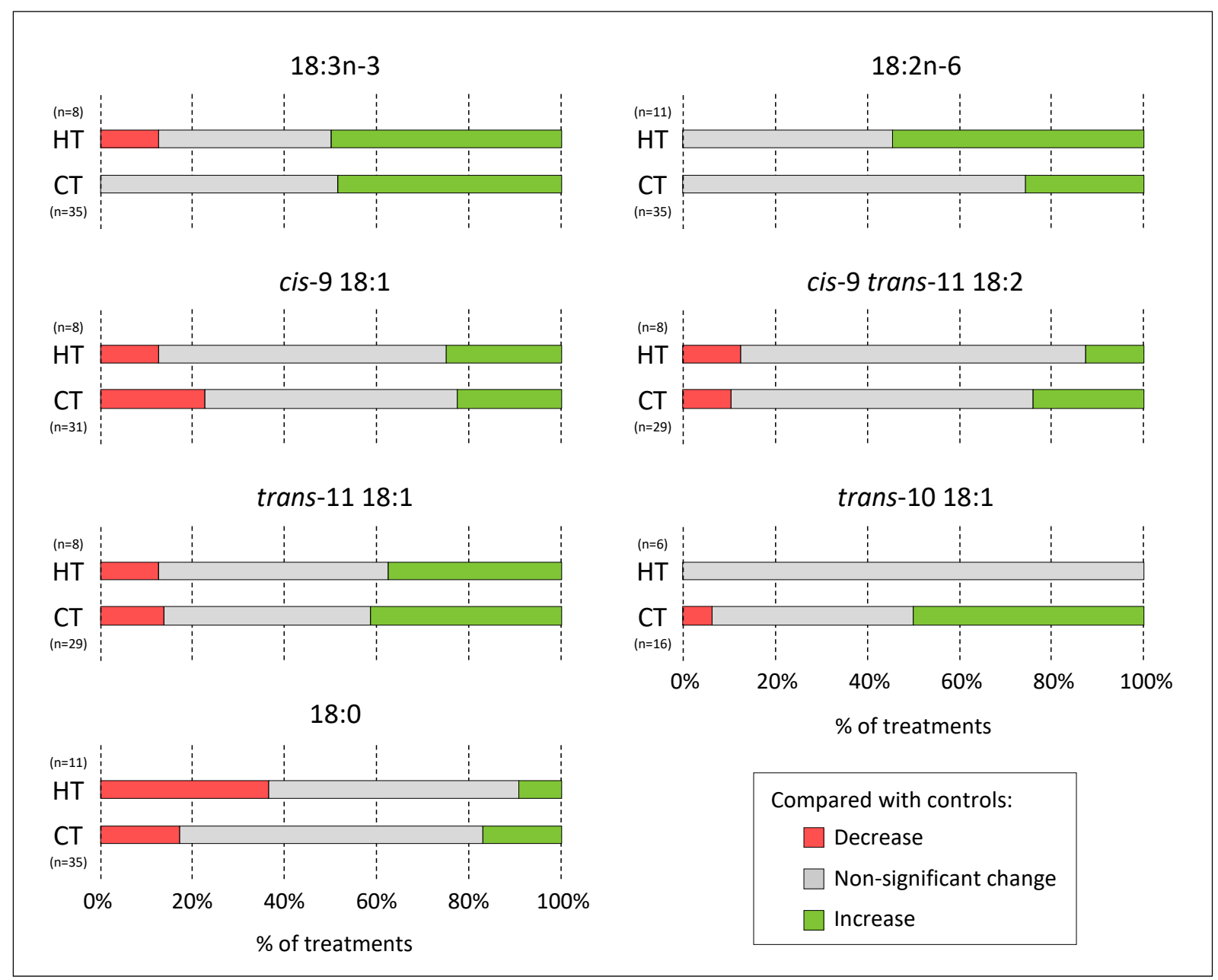


FIGURE 4

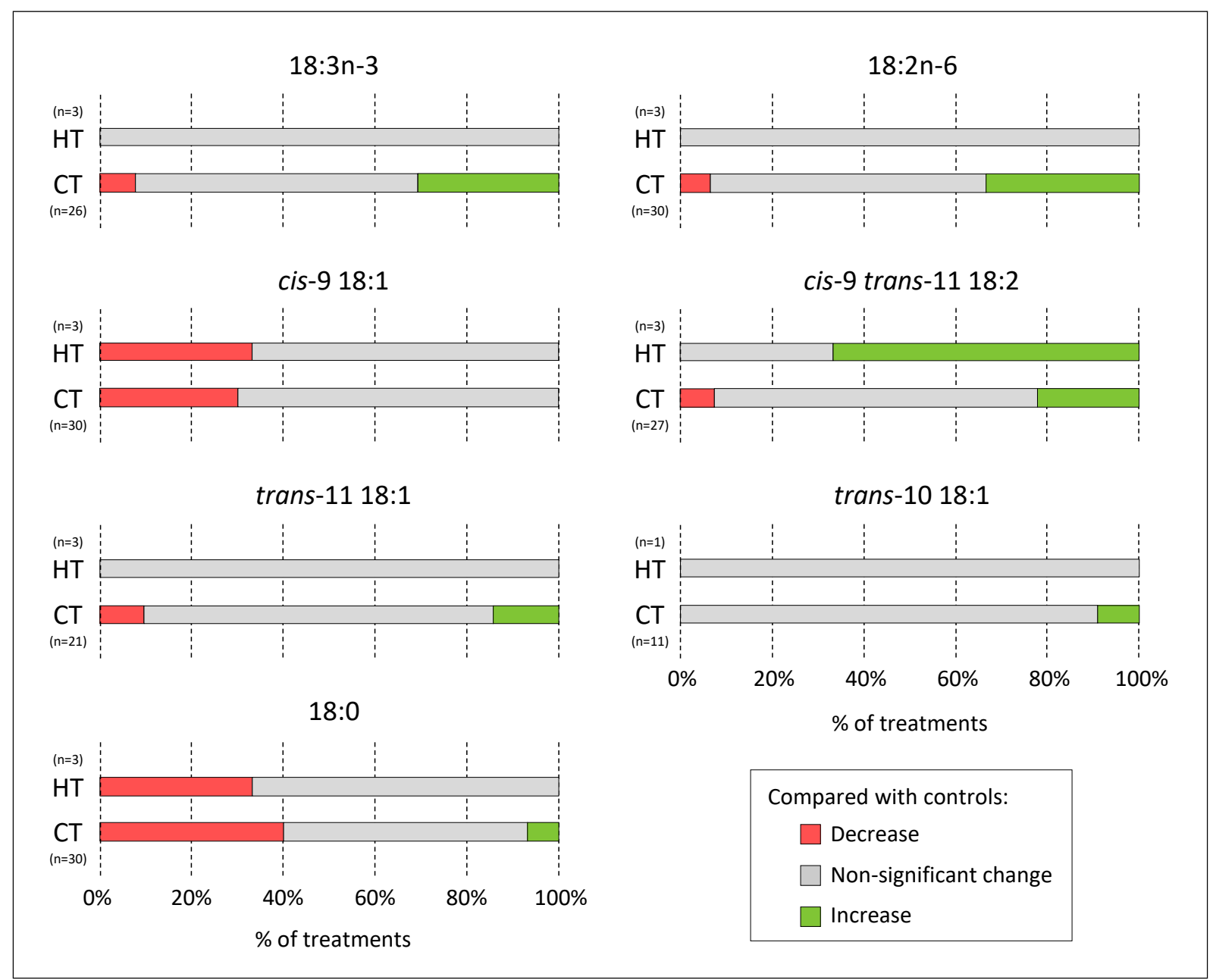


FIGURE 5

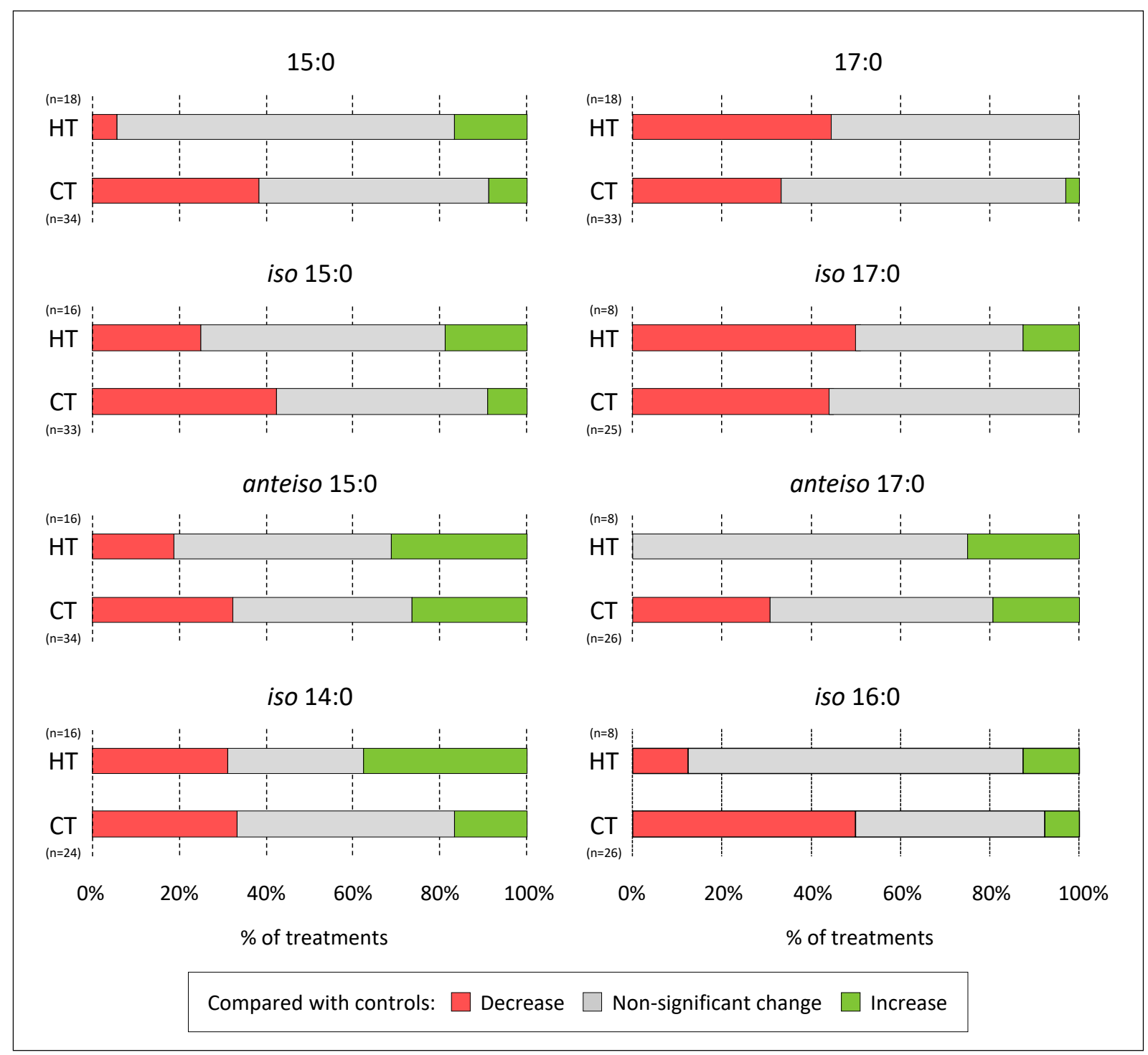




\section{SUPPLEMENTARY MATERIAL}

\section{References used for preparing Figures 2 and 5 (digesta fatty acid composition)}

Abo-Donia, F.M., Yang, L.Y., Hristov, A.N., Wang, M., Tang, S.X., Zhou, C.S., Han, X.F., Kang, J.H., Tan, Z.L., He, Z.X. 2017. Effects of tannins on the fatty acid profiles of rumen fluids and milk from lactating goats fed a total mixed ration containing rapeseed oil. Livest. Sci. 204, 16-24.

Al-Jumaili, W.S., Goh, Y.M., Jafari, S., Rajion, M.A., Jahromi, M.F., Ebrahimi, M. 2017. An in vitro study on the ability of tannic acid to inhibit methanogenesis and biohydrogenation of C18 PUFA in the rumen of goats. Ann. Anim. Sci. 17, 491-502.

Alves, S.P., Francisco, A., Costa, M., Santos-Silva, J., Bessa, R.J.B. 2017. Biohydrogenation patterns in digestive contents and plasma of lambs fed increasing levels of a tanniferous bush (Cistus ladanifer L.) and vegetable oils. Anim. Feed Sci. Technol. 225, 157-172.

Buccioni, A., Minieri, S., Rapaccini, S., Antongiovanni, M., Mele, M. 2011. Effect of chestnut and quebracho tannins on fatty acid profile in rumen liquid- and solid-associated bacteria: an in vitro study. Animal 5, 1521-1530.

Buccioni, A., Pallara, G., Pastorelli, R., Bellini, L., Cappucci, A., Mannelli, F., Minieri, S., Roscini, V., Rapaccini, S., Mele, M., Giovannetti, L., Viti, C., Pauselli, M. 2017. Effect of dietary chestnut or quebracho tannin supplementation on microbial community and fatty acid profile in the rumen of dairy ewes. Biomed Res. Int. 2017, 4969076.

Campidonico, L., Toral, P.G., Priolo, A., Luciano, G., Valenti, B., Hervás, G., Frutos, P., Copani, G., Ginane, C., Niderkorn, V. 2016. Fatty acid composition of ruminal digesta and longissimus muscle from lambs fed silage mixtures including red clover, sainfoin, and timothy. J. Anim. Sci. 94, 1550-1560.

Carreño, D., Hervás, G., Toral, P.G., Belenguer, A., Frutos, P. 2015. Ability of different types and doses of tannin extracts to modulate in vitro ruminal biohydrogenation in sheep. Anim. Feed Sci. Technol. 202, 45-51.

Correddu, F., Fancello, F., Chessa, L., Atzori, A.S., Pulina, G., Nudda, A. 2019. Effects of supplementation with exhausted myrtle berries on rumen function of dairy sheep. Small Rumin. Res. 170, 51-61.

Costa, M., Alves, S.P., Cabo, Â., Guerreiro, O., Stilwell, G., Dentinho, M.T., Bessa, R.J.B. 2017. Modulation of in vitro rumen biohydrogenation by Cistus ladanifer tannins compared with other tannin sources. J. Sci. Food Agric. 97, 629-635.

Guerreiro, O., Alves, S., Costa, M., Cabo, Â., Duarte, M., Jerónimo, E., Bessa, R.J.B. 2016. Effects of extracts obtained from Cistus ladanifer L. on in vitro rumen biohydrogenation. Anim. Feed Sci. Technol. 219, 304-312.

Heidarian Miri, V., Tyagi, A.K., Ebrahimi, S.H., Mohini, M. 2013. Plant extract enhanced ruminal CLA concentration, in vitro. J. Anim. Feed Sci. 22, 219-228.

Ishlak, A., Günal, M., AbuGhazaleh, A.A. 2015. The effects of cinnamaldehyde, monensin and quebracho condensed tannin on rumen fermentation, biohydrogenation and bacteria in continuous culture system. Anim. Feed Sci. Technol. 207, 31-40. 
Jeronimo, E., Alves, S.P., Dentinho, M.T.P., Martins, S.V., Prates, J.A.M., Vasta, V., SantosSilva, J., Bessa, R.J.B. 2010. Effect of grape seed extract, Cistus ladanifer L., and vegetable oil supplementation on fatty acid composition of abomasal digesta and intramuscular fat of lambs. J. Sci. Food Agric. 58, 10710-10721.

Khiaosa-ard, R., Bryner, S.F., Scheeder, M.R.L., Wettstein, H.R., Leiber, F., Kreuzer, M., Soliva, C.R. 2009. Evidence for the inhibition of the terminal step of ruminal alphalinolenic acid biohydrogenation by condensed tannins. J. Dairy Sci. 92, 177-188.

Kronberg, S.L., Scholljegerdes, E.J., Barcelo-Coblijn, G., Murphy, E.J. 2007. Flaxseed treatments to reduce biohydrogenation of alpha-linolenic acid by rumen microbes in cattle. Lipids 42, 1105-1111.

Minieri, S., Buccioni, A., Rapaccini, S., Pezzati, A., Benvenuti, D., Serra, A., Mele, M. 2014. Effect of quebracho tannin extract on soybean and linseed oil biohydrogenation by solid associated bacteria: an in vitro study. Ital. J. Anim. Sci. 13, 604-608.

Natalello, A., Hervás, G., Toral, P.G., Luciano, G., Valenti, B., Mendoza, A.G., Pauselli, M., Priolo, A., Frutos, P. 2020. Bioactive compounds from pomegranate by-products increase the in vitro ruminal accumulation of potentially health promoting fatty acids. Anim. Feed Sci. Technol. 259, 114355.

Rana, M.S., Tyagi, A., Hossain, S.A., Tyagi, A.K. 2012. Effect of tanniniferous Terminalia chebula extract on rumen biohydrogenation, $\Delta^{9}$-desaturase activity, CLA content and fatty acid composition in longissimus dorsi muscle of kids. Meat Sci. 90, 558-563.

Szczechowiak, J., Szumacher-Strabel, M., El-Sherbiny, M., Pers-Kamczyc, E., Pawlak, P., Cieslak, A. 2016. Rumen fermentation, methane concentration and fatty acid proportion in the rumen and milk of dairy cows fed condensed tannin and/or fish-soybean oils blend. Anim. Feed Sci. Technol. 216, 93-107.

Toral, P.G., Hervás, G., Missaoui, H., Andrés, S., Giráldez, F.J., Jellali, S., Frutos, P. 2016. Effects of a tannin-rich legume (Onobrychis viciifolia) on in vitro ruminal biohydrogenation and fermentation. Span. J. Agric. Res. 14, e0602.

Vasta, V., Makkar, H.P.S., Mele, M., Priolo, A. 2009a. Ruminal biohydrogenation as affected by tannins in vitro. Br. J. Nutr. 102, 82-92.

Vasta, V., Mele, M., Serra, A., Scerra, M., Luciano, G., Lanza, M., Priolo, A. 2009b. Metabolic fate of fatty acids involved in ruminal biohydrogenation in sheep fed concentrate or herbage with or without tannins. J. Anim. Sci. 87, 2674-2684.

Vasta, V., Yañez-Ruiz, D.R., Mele, M., Serra, A., Luciano, G., Lanza, M., Biondi, L., Priolo, A. 2010. Bacterial and protozoal communities and fatty acid profile in the rumen of sheep fed a diet containing added tannins. Appl. Environ. Microbiol. 76, 2549-2555. 


\section{References used for preparing Figure 3 (milk fatty acid composition)}

Abarghuei, M.J., Rouzbehan, Y., Salem, A.Z.M., Zamiri, M.J. 2014. Nitrogen balance, blood metabolites and milk fatty acid composition of dairy cows fed pomegranate-peel extract. Livest. Sci. 164, 72-80.

Abo-Donia, F.M., Yang, L.Y., Hristov, A.N., Wang, M., Tang, S.X., Zhou, C.S., Han, X.F., Kang, J.H., Tan, Z.L., He, Z.X. 2017. Effects of tannins on the fatty acid profiles of rumen fluids and milk from lactating goats fed a total mixed ration containing rapeseed oil. Livest. Sci. 204, 16-24.

Addis, M., Cabiddu, A., Pinna, G., Decandia, M., Piredda, G., Pirisi, A., Molle, G. 2005. Milk and cheese fatty acid composition in sheep fed Mediterranean forages with reference to conjugated linoleic acid cis-9, trans-11. J. Dairy Sci. 88, 3443-3454.

Alipanahi, Z., Fatahnia, F., Jafari, H., Taasoli, G., Mirzaei-Alamouti, H., Barrett, D., Pormalekshahi, A. 2019. Effect of oak acorn with or without polyethylene glycol in diets containing extruded soybean on milk fatty acid profile, ruminal fermentation and plasma metabolites of lactating goats. Livest. Sci. 221, 57-62.

Aprianita, A., Donkor, O.N., Moate, P.J., Williams, S.R.O., Auldist, M.J., Greenwood, J.S., Hannah, M.C., Wales, W.J., Vasiljevic, T. 2014. Effects of dietary cottonseed oil and tannin supplements on protein and fatty acid composition of bovine milk. J. Dairy Res. 81, 183-192.

Benchaar, C., Chouinard, P.Y., 2009. Assessment of the potential of cinnamaldehyde, condensed tannins, and saponins to modify milk fatty acid composition of dairy cows. J. Dairy Sci. 92, 3392-3396.

Bonanno, A., Di Grigoli, A., Mazza, F., De Pasquale, C., Giosuè, C., Vitale, F., Alabiso, M. 2016. Effects of ewes grazing sulla or ryegrass pasture for different daily durations on forage intake, milk production and fatty acid composition of cheese. Animal 10, 20742082 .

Buccioni, A., Pauselli, M., Minieri, S., Roscini, V., Mannelli, F., Rapaccini, S., Lupi, P., Conte, G., Serra, A., Cappucci, A., Brufani, L., Ciucci, F., Mele, M. 2017. Chestnut or quebracho tannins in the diet of grazing ewes supplemented with soybean oil: effects on animal performances, blood parameters and fatty acid composition of plasma and milk lipids. Small Rumin. Res. 153, 23-30.

Buccioni, A., Pauselli, M., Viti, C., Minieri, S., Pallara, G., Roscini, V., Rapaccini, S., Trabalza Marinucci, M., Lupi, P., Conte, G., Mele, M. 2015a. Milk fatty acid composition, rumen microbial population, and animal performances in response to diets rich in linoleic acid supplemented with chestnut or quebracho tannins in dairy ewes. J. Dairy Sci. 98, 11451156.

Buccioni, A., Serra, A., Minieri, S., Mannelli, F., Cappucci, A., Benvenuti, D., Rapaccini, S., Conte, G., Mele, M. 2015b. Milk production, composition, and milk fatty acid profile from grazing sheep fed diets supplemented with chestnut tannin extract and extruded linseed. Small Rumin. Res. 130, 200-207. 
Cabiddu, A., Molle, G., Decandia, M., Spada, S., Fiori, M., Piredda, G., Addis, M. 2009. Responses to condensed tannins of flowering sulla (Hedysarum coronarium L.) grazed by dairy sheep. Part 2: Effects on milk fatty acid profile. Livest. Sci. 123, 230-240.

das Neves Oiticica, I., da Fonseca, C.E.M., Lopes, F.C.F., Morenz, M.J.F., da Gama, M.A.S., de Souza, V.C., da Silva, A.B. 2019. Milk fatty acid composition of dairy goats fed increasing levels of Flemingia macrophylla hay. Semin. Cienc. Agrar. 40, 293-310.

de Lucena, A.R.F., Menezes, D.R., de Carvalho, D.T.Q., Matos, J.C., Antonelli, A.C., de Moraes, S.A., Dias, F.S., Queiroz, M.A.Á., Rodrigues, R.T.S. 2018. Effect of commercial tannin and a pornunça (Manihot spp.) silage-based diet on the fatty acid profile of Saanen goats' milk. Int. J. Dairy Technol. 71, 613-620.

Dschaak, C.M., Williams, C.M., Holt, M.S., Eun, J.S., Young, A.J., Min, B.R. 2011. Effects of supplementing condensed tannin extract on intake, digestion, ruminal fermentation, and milk production of lactating dairy cows. Journal of Dairy Science 94, 2508-2519.

Fagundes, G.M., Modesto, E.C., Saldanha, T., Fonseca, C.E.M., Muir, J.P., Vicente, J., Souza, V.C., Silva, A.B., Silva, R.M., Silva, J.B., Bueno, I.C.S. 2016. Effect of flavonoid compounds from Flemingia macrophylla on milk composition of lactating goat in the tropics, in: Combs, C.A. (Ed.) Tannins: Biochemistry, Food Sources and Nutritional Properties. Nova Science Publishers, New York, pp. 169-186.

Focant, M., Froidmont, E., Archambeau, Q., Dang Van, Q.C., Larondelle, Y. 2019. The effect of oak tannin (Quercus robur) and hops (Humulus lupulus) on dietary nitrogen efficiency, methane emission, and milk fatty acid composition of dairy cows fed a low-protein diet including linseed. J. Dairy Sci. 102, 1144-1159.

Girard, M., Dohme-Meier, F., Wechsler, D., Goy, D., Kreuzer, M., Bee, G. 2016. Ability of 3 tanniferous forage legumes to modify quality of milk and Gruyère-type cheese. J. Dairy Sci. 99, 205-220.

Henke, A., Westreicher-Kristen, E., Molkentin, J., Dickhoefer, U., Knappstein, K., Hasler, M., Susenbeth, A. 2017. Effect of dietary quebracho tannin extract on milk fatty acid composition in cows. J. Dairy Sci. 100, 6229-6238.

Lobón, S., Joy, M., Sanz, A., Álvarez-Rodríguez, J., Blanco, M. 2019. The fatty acid composition of ewe milk or suckling lamb meat can be used to discriminate between ewes fed different diets. Anim. Prod. Sci. 59, 1108-1118.

Maamouri, O., Mahouachi, M., Kraiem, K., Atti, N. 2019. Milk production, composition and milk fatty acid profile from grazing ewes fed diets supplemented with Acacia cyanophylla leaves as tannins source and whole or extruded linseed. Livest. Sci. 227, 120-127.

Moats, J., Mutsvangwa, T., Refat, B., Christensen, D.A. 2018. Evaluation of whole flaxseed and the use of tannin-containing fava beans as an alternative to peas in a co-extruded flaxseed product on ruminal fermentation, selected milk fatty acids, and production in dairy cows. Prof. Anim. Sci. 34, 435-446.

Pascual, A., Pineda-Quiroga, C., Goiri, I., Atxaerandio, R., Ruiz, R., García-Rodríguez, A. 2019. Effects of feeding UFA-rich cold-pressed oilseed cakes and sainfoin on dairy ewes' milk fatty acid profile and curd sensory properties. Small Rumin. Res. 175, 96-103. 
Roy, N.C., Knight, T.W., Reynolds, G.W., Deighton, M.H., Death, A.F., Sinclair, B.R., Peters, J.S., McNabb, W.C. 2002. The effect of condensed-tannins in fresh Sulla (Hedysarum coronarium) on the net flux of fatty acids across the mammary gland and their secretion in the milk of lactating ewes. Proc. New Zeal. Soc. Anim. Prod. 62, 231-235.

Toral, P.G., Hervás, G., Belenguer, A., Bichi, E., Frutos, P. 2013. Effect of the inclusion of quebracho tannins in a diet rich in linoleic acid on milk fatty acid composition in dairy ewes. J. Dairy Sci. 96, 431-439.

Turner, S.-A., Waghorn, G.C., Woodhard, S.L., Thomson, N.A. 2005. Condensed tannins in birdsfoot trefoil (Lotus corniculatus) affect the detailed composition of milk from dairy cows. Proc. New Zeal. Soc. Anim. Prod. 65, 283-289. 


\section{References used for preparing Figure 4 (meat fatty acid composition)}

Biondi, L., Randazzo, C.L., Russo, N., Pino, A., Natalello, A., Van Hoorde, K., Caggia, C. 2019. Dietary supplementation of tannin-extracts to lambs: effects on meat fatty acids composition and stability and on microbial characteristics. Foods 8, 469.

Brogna, D.M.R., Tansawat, R., Cornforth, D., Ward, R., Bella, M., Luciano, G., Priolo, A., Villalba, J. 2014. The quality of meat from sheep treated with tannin-and saponin-based remedies as a natural strategy for parasite control. Meat Sci. 96, 744-749.

Campidonico, L., Toral, P.G., Priolo, A., Luciano, G., Valenti, B., Hervás, G., Frutos, P., Copani, G., Ginane, C., Niderkorn, V. 2016. Fatty acid composition of ruminal digesta and longissimus muscle from lambs fed silage mixtures including red clover, sainfoin, and timothy. J. Anim. Sci. 94, 1550-1560.

Francisco, A., Alves, S.P., Portugal, P.V., Dentinho, M.T., Jerónimo, E., Sengo, S., Almeida, J., Bressan, M.C., Pires, V.M.R., Alfaia, C.M., Prates, J.A.M., Bessa, R.J.B., SantosSilva, J. 2018. Effects of dietary inclusion of citrus pulp and rockrose soft stems and leaves on lamb meat quality and fatty acid composition. Animal 12, 872-881.

Gesteira, S.M., Oliveira, R.L., da Silva Trajano, J., Ribeiro, C.V.D.M., de Sousa Costa, E.I., Ribeiro, R.D.X., Pereira, E.S., Bezerra, L.R. 2019. Fatty acid profile, physicochemical composition and sensorial attributes of salted and sun-dried meat from young Nellore bulls supplemented with condensed tannins. PLOS ONE, 14, e0216047

Girard, M., Dohme-Meier, F., Silacci, P., Ampuero Kragten, S., Kreuzer, M., Bee, G. 2016. Forage legumes rich in condensed tannins may increase n-3 fatty acid levels and sensory quality of lamb meat. J. Sci. Food Agric. 96, 1923-1933.

Gravador, R.S., Luciano, G., Jongberg, S., Bognanno, M., Scerra, M., Andersen, M.L., Lund, M.N., Priolo, A. 2015. Fatty acids and oxidative stability of meat from lambs fed carobcontaining diets. Food Chem. 182, 27-34.

Guerreiro, O., Alves, S.P., Soldado, D., Cachucho, L., Almeida, J.M., Francisco, A., SantosSilva, J., Bessa, R.J. Jerónimo, E., 2020. Inclusion of the aerial part and condensed tannin extract from Cistus ladanifer L. in lamb diets-Effects on growth performance, carcass and meat quality and fatty acid composition of intramuscular and subcutaneous fat. Meat Sci. 160, 107945.

Jerónimo, E., Alfaia, C.M., Alves, S.P., Dentinho, M.T., Prates, J.A., Vasta, V., Santos-Silva, J., Bessa, R.J. 2012. Effect of dietary grape seed extract and Cistus ladanifer L. in combination with vegetable oil supplementation on lamb meat quality. Meat Sci. 92, 841847.

Kamel, H.E.M., Al-Dobaib, S.N., Salem, A.Z., López, S., Alaba, P.A. 2018. Influence of dietary supplementation with sunflower oil and quebracho tannins on growth performance and meat fatty acid profile of Awassi lambs. Anim. Feed Sci. Technol. 235, 97-104.

Larraín, R.E., Schaefer, D.M., Richards, M.P., Reed, J.D. 2008. Finishing steers with diets based on corn, high-tannin sorghum or a mix of both: Color and lipid oxidation in beef. Meat Sci. 79, 656-665. 
Lee, J.H., Min, B.R., Lemma, B.B. 2017. Quality characteristics of goat meat as influenced by condensed tannins-containing pine bark. Small Rumin. Res. 146, 28-32.

Lobón, S., Blanco, M., Sanz, A., Ripoll, G., Bertolín, J.R., Joy, M. 2017. Meat quality of light lambs is more affected by the dam's feeding system during lactation than by the inclusion of quebracho in the fattening concentrate. J. Anim. Sci. 95, 4998-5011.

Majewska, M.P., Kowalik, B. 2020. Growth performance, carcass characteristics, fatty acid composition, and blood biochemical parameters of lamb fed diet with the addition of lingonberry leaves and oak bark. Eur. J. Lipid Sci. Technol. 122, 1900273.

Mapiye, C., Chimonyo, M., Dzama, K., Hugo, A., Strydom, P.E., Muchenje, V. 2011. Fatty acid composition of beef from Nguni steers supplemented with Acacia karroo leaf-meal. J. Food Compos. Anal. 24, 523-528.

Priolo, A., Bella, M., Lanza, M., Galofaro, V., Biondi, L., Barbagallo, D., Salem, H.B., Pennisi, P. 2005. Carcass and meat quality of lambs fed fresh sulla (Hedysarum coronarium L.) with or without polyethylene glycol or concentrate. Small Rumin. Res. 59, 281-288.

Rana, M.S., Tyagi, A., Hossain, S.A., Tyagi, A.K. 2012. Effect of tanniniferous Terminalia chebula extract on rumen biohydrogenation, $\Delta 9$-desaturase activity, CLA content and fatty acid composition in longissimus dorsi muscle of kids. Meat Sci. 90, 558-563.

Seoni, E., Battacone, G., Silacci, P., Ampuero Kragten, S., Messadene Chelali, J., DohmeMeier, F., Bee, G. 2018. Effect of condensed tannins from Birdsfoot trefoil and dietary protein level on growth performance, carcass composition and meat quality of ram lambs. Small Rum. Rese. 169, 118-126.

Turner, K.E., Cassida, K.A., Zerby, H.N., Brown, M.A. 2015. Carcass parameters and meat quality in meat-goat kids finished on chicory, birdsfoot trefoil, or red clover pastures. Meat Sci. 105, 68-74.

Vasta, V., Pennisi, P., Lanza, M., Barbagallo, D., Bella, M., Priolo, A. 2007. Intramuscular fatty acid composition of lambs given a tanniniferous diet with or without polyethylene glycol supplementation. Meat Sci. 76, 739-745.

Vasta, V., Mele, M., Serra, A., Scerra, M., Luciano, G., Lanza, M., Priolo, A. 2009. Metabolic fate of fatty acids involved in ruminal biohydrogenation in sheep fed concentrate or herbage with or without tannins. J. Anim. Sci. 87, 2674-2684.

Whitney, T.R., Smith, S.B. 2015. Substituting redberry juniper for oat hay in lamb feedlot diets: Carcass characteristics, adipose tissue fatty acid composition, and sensory panel traits. 